\title{
A Comprehensive Review on Surface Modifications of Biodegradable Magnesium-Based Implant Alloy: Polymer Coatings Opportunities and Challenges
}

\author{
Abbas Saberi ${ }^{1}$, Hamid Reza Bakhsheshi-Rad ${ }^{1,2}$ * , Somayeh Abazari ${ }^{3}$, Ahmad Fauzi Ismail ${ }^{4}$, Safian Sharif ${ }^{2}$, \\ Seeram Ramakrishna ${ }^{5}$ (D), Mohammadreza Daroonparvar ${ }^{6, *}$ and Filippo Berto ${ }^{7, *}$ \\ 1 Advanced Materials Research Center, Department of Materials Engineering, Najafabad Branch, \\ Islamic Azad University, Najafabad, Iran; abbassaberi65@gmail.com \\ 2 Faculty of Engineering, Universiti Teknologi Malaysia, Johor Bahru, Johor 81310, Malaysia; safian@utm.my \\ 3 Department of Materials and Metallurgical Engineering, Amirkabir University of Technology, Tehran, Iran; \\ somayeh.abazari@gmail.com \\ 4 Advanced Membrane Technology Research Center (AMTEC), Universiti Teknologi Malaysia, Johor Bahru, \\ Johor 81310, Malaysia; afauzi@utm.my \\ 5 Department of Mechanical Engineering, National University of Singapore, 9 Engineering Drive 1, \\ Singapore 117576, Singapore; seeram@nus.edu.sg \\ 6 Department of Chemical and Materials Engineering, University of Nevada, Reno, NV 89501, USA \\ 7 Department of Mechanical and Industrial Engineering, Norwegian University of Science and Technology, \\ 7491 Trondheim, Norway \\ check for \\ updates \\ * Correspondence: rezabakhsheshi@gmail.com (H.R.B.-R.); mr.daroonparvar@yahoo.com (M.D.); \\ filippo.berto@ntnu.no (F.B.)
}

Citation: Saberi, A.; Bakhsheshi-Rad, H.R.; Abazari, S.; Ismail, A.F.; Sharif,

S.; Ramakrishna, S.; Daroonparvar,

M.; Berto, F. A Comprehensive

Review on Surface Modifications of Biodegradable Magnesium-Based Implant Alloy: Polymer Coatings Opportunities and Challenges. Coatings 2021, 11, 747. https:// doi.org/10.3390/coatings11070747

Academic Editor: Devis Bellucci

Received: 29 April 2021

Accepted: 15 June 2021

Published: 22 June 2021

Publisher's Note: MDPI stays neutral with regard to jurisdictional claims in published maps and institutional affiliations.

Copyright: (c) 2021 by the authors. Licensee MDPI, Basel, Switzerland. This article is an open access article distributed under the terms and conditions of the Creative Commons Attribution (CC BY) license (https:/ / creativecommons.org/licenses/by/ $4.0 /)$.
Abstract: The development of biodegradable implants is certainly intriguing, and magnesium and its alloys are considered significant among the various biodegradable materials. Nevertheless, the fast degradation, the generation of a significant amount of hydrogen gas, and the escalation in the $\mathrm{pH}$ value of the body solution are significant barriers to their use as an implant material. The appropriate approach is able to solve this issue, resulting in a decrease the rate of $\mathrm{Mg}$ degradation, which can be accomplished by alloying, surface adjustment, and mechanical treatment. Surface modification is a practical option because it not only improves corrosion resistance but also prepares a treated surface to improve bone regeneration and cell attachment. Metal coatings, ceramic coatings, and permanent polymers were shown to minimize degradation rates, but inflammation and foreign body responses were also suggested. In contrast to permanent materials, the bioabsorbable polymers normally show the desired biocompatibility. In order to improve the performance of drugs, they are generally encapsulated in biodegradable polymers. This study summarized the most recent advancements in manufacturing polymeric coatings on $\mathrm{Mg}$ alloys. The related corrosion resistance enhancement strategies and future potentials are discussed. Ultimately, the major challenges and difficulties are presented with aim of the development of polymer-coated $\mathrm{Mg}$-based implant materials.

Keywords: synthetic polymer coatings; polymer coatings; magnesium-based alloy; corrosion behavior; biocompatibility

\section{Introduction}

As a result of their superior mechanical properties, metal implants are often used to heal bone fractures. Stainless steel, Ti-based alloys and Co-based alloys are also highly available commercially bone implant materials. Metals are preferred for long-term, stable, and load-bearing implants due to their high strength and excellent ductility, which results in high fracture resistance. Furthermore, metal implants with complicated architecture can be manufactured using a variety of available manufacturing technology such as casting, machining, and powder metallurgy. Implants must be biocompatible and have mechanical 
properties that are compatible with bone. Corrosion and wear have an effect on the biocompatibility of metallic implants. In metal implants, hazardous metal ions caused by corrosion and wear can cause inflammation, cell apoptosis, and other tissue reactions. It has been stated that the releasing of $\mathrm{Co}-\mathrm{Cr}$ alloys, $\mathrm{Nb}$, and ions can trigger harmful tissue reactions by increasing the permissible limits of these materials in body. $\mathrm{Ni}$, for example, is a cytotoxic, genotoxic, carcinogenic, and mutagenic element [1-3].

Thus, biodegradable metals (BMs) were designed to resolve these concerns and to prevent the second surgery from removing metallic implants following the restoration of tissue function [4]. Zinc ( $\mathrm{Zn})$, magnesium $(\mathrm{Mg})$, and iron $(\mathrm{Fe})$ are the three first and most basic biodegradable metals. Magnesium normally degrades too quickly (in 1-4 months), resulting in hydrogen evolution gas that is detrimental. Meanwhile, the degradation time of Fe base materials is very slow (more than 2-3 years), and its products are sustained in tissues for a long time [5-7]. Furthermore, the by-products from the corrosion are retained in the body for a long time in biological matrices and healed from the body at a low rate [4]. As a result, Fe is unsuitable for use in biomedical applications unless its corrosion rate is modified [8]. However, the degradation rate of zinc is between magnesium and iron; it is lower than $\mathrm{Mg}$ and higher than $\mathrm{Fe}$ [5]. As a result, $\mathrm{Zn}$ has recently received a lot of attention. Nonetheless, its low strength and ductility limit its use in load-bearing applications [8]. In addition, a high release of pure $\mathrm{Zn}$ more than $100-300 \mathrm{mg}$ /day leads to health issues [9]. Therefore, in comparison to other BMs, magnesium and also its alloys have a low elastic modulus (40-45 GPa), a high strength, and a low density $\left(1.7-2.0 \mathrm{~g} / \mathrm{cm}^{3}\right)[9,10]$. Their elastic modulus is similar to human bone, reducing the stress-shielding effect. $\mathrm{Mg}$ is also an important nutrient that performs numerous biological functions in the human body [11] As a result, Mg-based BMs have found their way into a variety of biomedical applications, including internal fixation medical devices (such as pins, bone, and screws) and tissue engineering scaffolds [4].

Furthermore, $\mathrm{Mg}$ and its alloys vary from other biomaterials in that they have physical and mechanical characteristics that are consistent with human bone [1]. Mg has become a biodegradable substance that fully degrades in the body following medicinal use. Patients with bone fractures and dental problems require mechanical strength, biodegradability, bioactivity, and biocompatibility in the healing process. The development and use of $\mathrm{Mg}$ based products are determined by the application $[2,12,13]$. Mg-based materials are used in the development of cardiovascular stents, which can achieve the necessary angiographic results and safe desorption. From 6 to 12 months is a suitable time frame for coronary stents to finish the remodeling function of arterial vessels and operate with maximum mechanical integrity $[2,12,13]$. However, the primary issue with magnesium alloys is their poor corrosion resistance and rapid degradation rate in a human body fluid, which has restricted their use as implant materials in medicine [14]. Such an uncontrollable and rapid corrosion mechanism causes a major decrease in the mechanical properties of the bioimplants, resulting in premature failure [15-17]. Furthermore, the formation of hydrogen gas and the alkalinization of microenvironments near the implant/tissue interface create serious concerns about the patient's health $[18,19]$. Such negative effects may cause the healing process to be slowed or even necrosis of the local tissue. Thus, controlling the rate of corrosion/degradation of magnesium is critical to its clinical application [20]. For increasing $\mathrm{Mg}$ alloys' corrosion resistance, researchers have focused on mechanical alloying, composite formation, and surface engineering [21]. Alloying and surface modification, such as polymer coating, electrochemical deposition, chemical conversion, and micro-arc oxidation (MAO), are two of the most common methods for improving magnesium properties [22]. Alloying is effective for optimizing the structures and characteristics of the materials as a whole but incurs a high cost [23].

In addition to alloying, the surface modification technique is another effective approach to control the degradation rate of $\mathrm{Mg}$ alloy. From this perspective, polymer coating can be defined as coatings that use an inert surface to prevent contacting outside environments and substrates. The coating's protective properties are primarily determined by its 
stability and coverage of coating materials [23]. In addition, it was reported that biocompatible polymeric films are effective in increasing the corrosion resistance of $\mathrm{Mg}$ alloy because of the electrical insulation properties of the coatings, and there is no galvanic corrosion between film and substrate [24]. Furthermore, the degradation rate of biodegradable and biocompatible polymers is slowly through water absorption and hydrolysis, introducing bio-products incorporated into other metabolic pathways or removed from the body [25]. The controlled delivery of drugs in Mg-based materials with surface coatings, especially a variety of polymer coatings, also has been confirmed [26]. Additionally, polymeric materials have exceptional multifunctional properties that can be used in upcoming magnesium bio-implants (Figure 1). Thus, various types of polymer coatings, including poly(lactide-coglycolic) acid (PLGA), poly (glycolic acid) (PGA), collagen (Col), polycaprolactone (PCL), chitosan (CS), polylactic acid (PLA), fibrin, alginate, and other representative organic compounds are discussed in this review paper, as shown in Figure $2[27,28]$. Calcium phosphate $(\mathrm{Ca}-\mathrm{P})$ coatings, in addition to polymer coatings, improve the corrosion and wear resistance of $\mathrm{Mg}$ and its alloys. Ca-P coatings are available in different types, such as hydroxyapatite (HA) [24]. Ca-P is the most abundant inorganic ingredient in natural bone and also is a widespread coating on $\mathrm{Mg}$ and its alloys with great bioactivity and cytocompatibility $[24,29]$. Thus, metal/polymer and ceramic/polymer composite coatings, and also combinations of these two constituents, have been produced on $\mathrm{Mg}$ alloys in order to increase corrosion resistance, biocompatibility, and bioactivity [24]. This review also aims to provide a comprehensive description of the research status of polymer-coated and polymer-based composite-coated $\mathrm{Mg}$ and its alloys targeted for orthopedic applications. The influence of different polymers on $\mathrm{Mg}$ and its alloys' biodegradation performance and biocompatibility is comprehensively discussed [30]. Furthermore, we summarize the current understanding of the possible corrosion mechanisms of polymer-coated and polymer-based composite-coated Mg and its alloys based on the previous studies [26]. Finally, the major challenges and difficulties are summarized, with a focus on the promising research on polymer-coated $\mathrm{Mg}$-based implant materials.

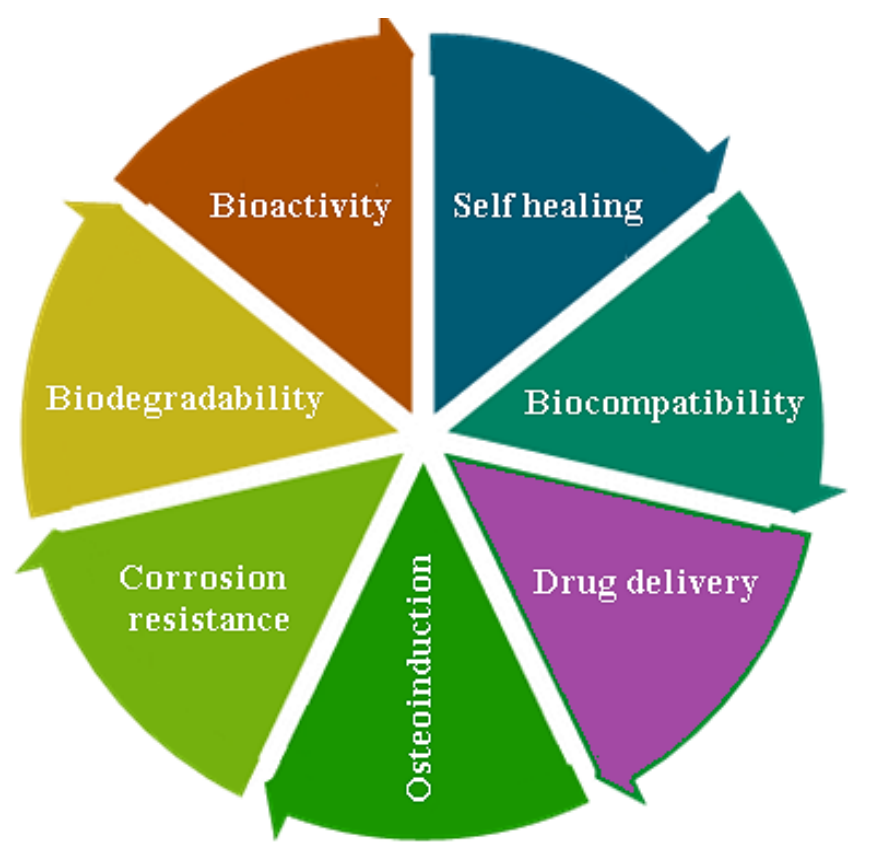

Figure 1. Diverse functionalities of polymer coatings for biodegradable Mg alloys. 
<smiles>CNC(=O)CNC(=O)CN</smiles>

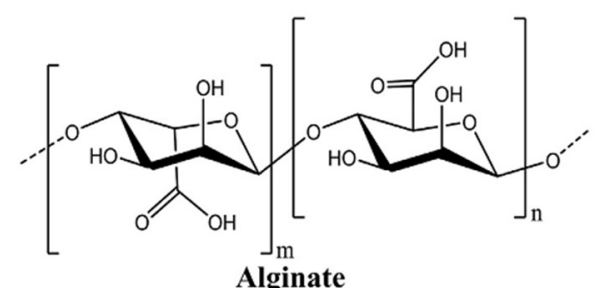

Alginate

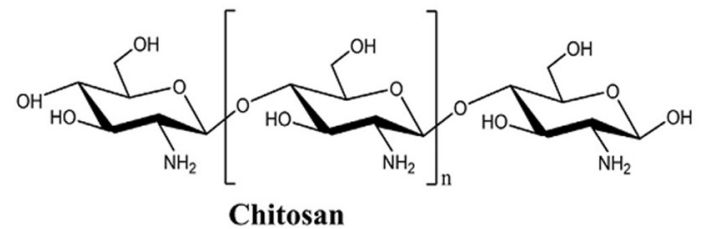

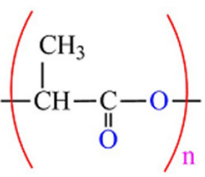

Poly (lactic acid)<smiles>CCC(C)OCC(=O)COC</smiles>

Poly (glycolic acid)

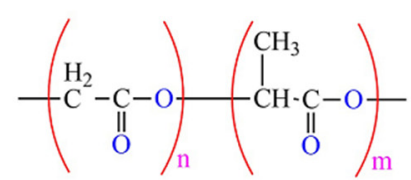

Poly (lactide-co-glycolide)

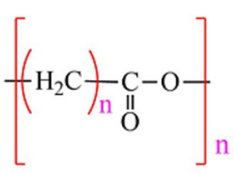

Polycaprolactone

Figure 2. Chemical structures of representative natural and synthetic biomaterials. Reprinted with permission from [27,28]; Copyright 2017\&2019 Elsevier.

\section{Synthetic Polymer Coatings}

\subsection{Polylactic Acid (PLA) Coated on Mg Alloy}

As a biodegradable polymer, PLA has a Young's modulus of about $3 \mathrm{GPa}$, an ultimate tensile of 50-70 MPa with about $4 \%$ elongation at separation, and fracture toughness of about $2.5 \mathrm{~kJ} / \mathrm{m}^{2}$ [31]. For medical uses, PLA is extensively investigated. This polymer is biocompatible, hydrolytically degrades in body fluid, and their products are nontoxic. However, a significant disadvantage of these polymers for use regarding a load-bearing orthopedic implant compared to natural bone is having low mechanical properties. In this respect, PLA coatings can be effective because they are biocompatible, biodegradable, and, most importantly, have a low degradation rate. PLA degrades hydrolytically through the bulk erosion process, which involves the ester backbone being randomly broken. A by-product of human metabolism, lactic acid degrades into carbon dioxide and water through the citric acid cycle [32]. Table 1 shows the effect of synthetic polymer coating and composite coatings parameters on magnesium-based properties. Sheng et al. [33] showed that poly(L-lactic acid) (PLLA) coatings have the potential to escalate corrosion resistance and reduce substrate corrosion rates significantly. Likewise, Zhang et al. [34] fabricated PLA/brushite on a Mg alloy with high interfacial bonding strength to improve biocorrosion resistance and cell response.

Alabbasi et al. [32] used a spin-coating technique to coat PLA on a biodegradable $\mathrm{Mg}$ alloy (AZ91; $9 \mathrm{wt} \% \mathrm{Al}$ and $1 \mathrm{wt} \% \mathrm{Zn}$ ) as temporary medical applications. The degradation behavior of the coated alloy samples was studied employing electrochemical impedance spectroscopy (EIS) in simulated body fluid (SBF). According to EIS analysis, the PLA coating greatly improved the alloy's corrosion resistance. Increased PLA coating thickness was proven to raise degradation resistance; for example, a $5 \mu \mathrm{m}$ thick PLA coating demonstrated more than two times higher corrosion resistance than bare metal, but higher coating thickness leads to poor adhesion [32]. A thin-film coating $(\approx 3 \mu \mathrm{m})$ applied to the alloy demonstrated strong adhesion and degradation resistance. Even after $48 \mathrm{~h}$ of exposure, the PLA-coated samples' corrosion resistance was considerably higher than that of the bare metal; the polarization resistance $\left(R_{\mathrm{p}}\right)$ of the magnesium alloy coated with $1.8 \mu \mathrm{m}$ and $5 \mu \mathrm{m}$ PLA after immersion in SBF is $9.5 \times 10^{3}$ and $6 \times 10^{4} \Omega \cdot \mathrm{cm}^{2}$ respectively, despite the fact that their corrosion resistance decreased steadily as the SBF exposure time increased [32].

Li et al. [35] applied on AZ31 alloy discs (AZ31; 3 wt \% Al and 1 wt \% Zn), hydroxyapatite/calcium titanate/titanium dioxide/polylactic acid ( $\left.\mathrm{HA} / \mathrm{CaTiO}_{3} / \mathrm{TiO}_{2} / \mathrm{PLA}\right)$ 
composite coatings, and the electrochemical properties were studied using electrochemical tests and immersion corrosion tests (Figure 3) [35]. Due to their obvious poor adhesion, the ceramic and polymer layer have very close resistance to corrosion in immersion corrosion tests. Meanwhile, the composite coating containing $\mathrm{HA}$ and $\mathrm{TiO}_{2}$ is a suitable protective film that demonstrated the lower corrosion rate of all the coatings studied in this paper. The $\mathrm{TiO}_{2}$ interlayer strengthens the bonding strength between HA and PLA, resulting in a $\mathrm{HA} / \mathrm{TiO}_{2} / \mathrm{PLA}$ coating that combines the benefits of organic and inorganic coatings. An $\mathrm{HA}$ lattice is roughly six times the size of a $\mathrm{TiO}_{2}$ lattice. The hydroxyl number of a HA lattice, on the other hand, is only half that of a $\mathrm{TiO}_{2}$ lattice handled by a team, and the latter is directional outwards. $\mathrm{Ti}-\mathrm{OH}$ on a $\mathrm{TiO}_{2}$ film conforms chemical hydrogen bonds with PLA more effectively and with less effect than HA. When compared to the HA/PLA interface, the amount of hydrogen bonds on the $\mathrm{TiO}_{2} / \mathrm{PLA}$ interface can boost significantly, which has a noticeable effect on the performance of the coating [35]. In addition, the significant corrosion resistance of $\mathrm{HA} / \mathrm{CaTiO} 3 / \mathrm{TiO}_{2} / \mathrm{PLA}$ could be due to the high adhesion strength of the $\mathrm{TiO}_{2}$ layer and underlayer. When compared to the uncoated sample $(-1.607 \mathrm{~V})$, the $E_{\text {corr }}$ of $\mathrm{HA} / \mathrm{TiO}_{2} / \mathrm{PLA}$ enhanced to $-0.430 \mathrm{~V}$, and the $i_{\text {corr }}$ lowered by five orders of magnitude, which implies the high protectiveness effect of the composite layer against corrosion attacks [35]. In this regard, the $i_{\text {corr }}$ of the bare sample, HA, HA/PLA, and $\mathrm{HA} / \mathrm{CaTiO}_{3} / \mathrm{TiO}_{2} / \mathrm{PLA}$ specimens were $34.8,17.64,5.98$, and $8.913 \times 10^{-4} \mu \mathrm{A} / \mathrm{cm}^{2}$, implying higher corrosion resistance of the coating and its essential role to protect from the underlayer [35].

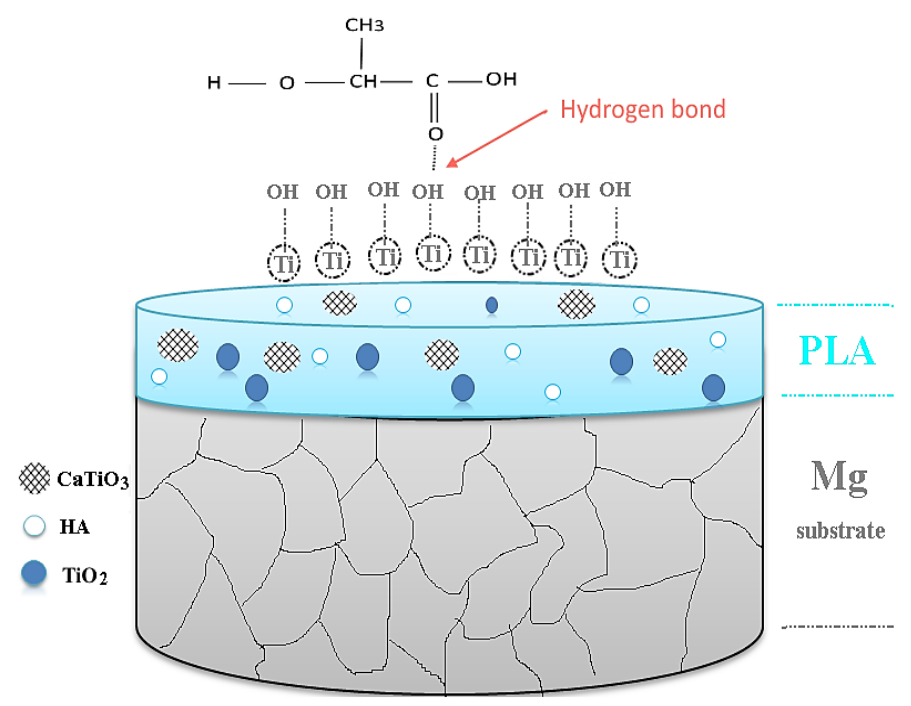

Figure 3. Sketch of adhesion mechanism of $\mathrm{HA} / \mathrm{CaTiO}_{3} / \mathrm{TiO}_{2} / \mathrm{PLA}$ coating. Reprinted with permission from [35]; Copyright 2016 Elsevier.

Shi et al. [36] employed micro-arc oxidation (MAO) combined with PLA sealing to create PLA/MAO film on AZ31 magnesium. The MAO process was conducted in an electrolyte containing $40 \mathrm{~g} / \mathrm{L} \mathrm{NaOH}$ and $4 \mathrm{~g} / \mathrm{L} \mathrm{KF}$. By MAO treatment, a porous $\mathrm{MgO}$ layer with a thickness of about $5 \mu \mathrm{m}$ was established on AZ31 alloy, and the PLA sealing was accomplished by dip coating with a thickness of about $9 \mu \mathrm{m}$. The bonding strength measured between the film and underlayer is $45 \mathrm{MPa}$, which is greater than the adhesive strength measured among the PLA coating and AZ31 alloy. The present study proposes a mechanical interlocking and $\mathrm{MgO}$ chemical bond model to exemplify the bonding mechanisms at the interfaces of coated film and substrate [36]. The surface roughness of the $\mathrm{MgO}$ layer may contribute to the mechanical interlocking of the PLA and AZ31 alloy. The MgO bond that formed as a result of the PLA-AZ31 reaction contributes to the chemical bond among the PLA and underlayer. The PLA coating could considerably enhance the anticorrosion property of bare alloy and AZ31/MAO in SBF. The anode in 
the MAO method is a magnesium alloy, and the cathode is a stainless steel cylindrical container. At first, high voltage causes the temperature to rise, an oxide film forms on the $\mathrm{Mg}$ alloy surface, and severe $\mathrm{H}_{2}$ evolution can be observed. So, the voltage gradually increases at a slower rate; at weak points in the oxide film, it breaks, and the film thickness enhances $[21,22,37]$. The electrolyte diffuses into the discharge channels formed on the $\mathrm{Mg}$ substrate's surface due to the strong spark discharge [21,37]. The high voltage with an extremely high temperature in the discharge channel turns the electrolyte inside the channels into plasma; after that, there is a plasma chemical reaction. Metallic ions are released from the $\mathrm{Mg}$ alloy and drift away from the $\mathrm{Mg}$ alloy, and simultaneously, oxygen ions move in the inverse direction. Then, the oxide is formed on the Mg alloys' surface because of the reaction between oxygen ions and $\mathrm{Mg}$ ions, and a ceramic-like porous coating is formed on the Mg alloy [21,22,37].

As compared to the AZ31 substrate, the PLA-AZ31 and MAO-AZ31 corrosion potentials shifted positively by around $110 \mathrm{mV}$. Corrosion current density drops from bare AZ31 $\left(611.71 \mu \mathrm{A} / \mathrm{cm}^{2}\right)$ to PLA-AZ31 $\left(7.72 \mu \mathrm{A} / \mathrm{cm}^{2}\right)$ and MAO-AZ31 $\left(66.32 \mu \mathrm{A} / \mathrm{cm}^{2}\right)$. The corrosion potential of PLA-MAO-AZ31 was greater $(-1.51 \mathrm{~V})$; however, the corrosion current density was much lower $\left(1.83 \mu \mathrm{A} / \mathrm{cm}^{2}\right)$. This meant that the PLA layer's efficient sealing prevented corrosive ions from permeating the cracks and vents, thus increasing the $\mathrm{MgO}$ coating corrosion resistance. MAO/PLA composite coatings with high adhesive strength and corrosion resistance can be an attractive option for the surface modification of $\mathrm{Mg}$ alloys in order to slow their degradation rate in SBF [36]. The study of Bakhsheshi-Rad [38] showed the feasibility of preparing a PLA layer on a microarc oxidation (MAO)-coated $\mathrm{Mg}-\mathrm{Ca}$ alloy via a relatively simple method. The contact angle increases significantly from $42.30^{\circ}$ for the uncoated alloy to $95.30^{\circ}$ for the duplex coating as a result of composite coating. The MAO/PLA coating has a lower adhesive strength (14.7 MPa) than the MAO coating (23.4 MPa). The double layer MAO/PLA coating has a significantly lower corrosion current density and a higher charge transfer resistance than the single layer MAO coating. Their results also reveal that wrapping the pores of the MAO layer with PLA polymer coating significantly improves the Mg alloy's corrosion resistance in the SBF physiological environment, demonstrating the MAO treatment's potential for biomedical applications. Wei et al. [39] obtained a PEO/PLLA composite coating on AZ31 alloy. The porous surface is fully covered after PLLA treatment. In vitro tests revealed a significant decrease in degradation rate, a hemolysis ratio lower than $0.80 \%$, and good attachment and growth of MC3T3-E1 cells on the coating. Zeng et al. [40] prepared MAO/PLLA composite coatings on a $\mathrm{Mg}-\mathrm{Li}-\mathrm{Ca}$ alloy substrate. Their findings show that $\mathrm{MAO}$ coatings can preserve the substrate only during the initial limited immersion period; after that, because of pores and microcracks in the coating, the corrosion rate accelerates. The formation of PLLA on top of the MAO film seals the pores and reduces the medium's penetration into the substrate [41].

\subsection{Poly (Lactide-Co-Glycolic) Acid (PLGA) Coated on Mg-Based Alloy}

PLGA copolymers with great biocompatibility are one of the few synthetic polymers approved for use in human clinical trials. They are also biodegradable by simply hydrolyzing the lactic and glycolic acid ester bonds that are excreted by normal metabolism. Furthermore, by changing the ratio of the two co-monomers, PLGA is easily processed and has controllable degradation properties [42]. Biocompatibility and corrosion properties of the PLGA-coated $\mathrm{Mg}-6 \mathrm{Zn}$ alloy are investigated by Li et al. [42]. For the dip-coating process, the PLGA was dissolved in chloroform with concentrations of 2 and $4 \mathrm{wt} \%$. The bare alloy, on the other hand, did not have a reasonable corrosion/degradation rate. The degradation rate was substantially reduced when the PLGA coating was applied. The $E_{\text {corr }}$ of two polymer coatings ( $2 \%$ and $4 \%$ PLGA) is significantly lower than that of the bare alloy, but the $i_{\text {corr }}$ of samples are much lower, by at least two orders of magnitude, as compared to the bare alloy. For the $2 \%$ PLGA coating, breakdowns potential $\left(E_{b d}\right)$ emerged in the anodic branch of the polarization curve, suggesting that the protective films were destroyed at a later stage of the experiment. The $E_{b d}$ of $-1.3 \mathrm{~V}$ measured here is greater than the $E_{b d}$ 
of $\mathrm{Mg}$ alloy measured in the $0.9 \% \mathrm{NaCl}$ solution $(\approx-1.55 \mathrm{~V})$. The PLGA coatings protect the $\mathrm{Mg}$ substrates, as shown by the above findings [42]. Similarly, a microarc oxidation (MAO)+PLGA composite coating was applied on the $\mathrm{Mg}-4 \mathrm{Zn}-0.6 \mathrm{Zr}-0.4 \mathrm{Sr}$ alloy by $\mathrm{Chen}$ et al. [43]. The MAO+PLGA coating dramatically enhances corrosion resistance while also improving stress corrosion cracking (SCC) resistance and mechanical stability over a long period, as shown in Figure 4 [43]. As compared to the uncoated Mg alloy, the MAO+PLGA coating enhanced Mg alloy's corrosion resistance by around three orders of magnitude, and the SCC susceptibility measurements decreased by $75 \%$ of ultimate tensile stress and $50 \%$ of strain to failure. The failure of the MAO coating after $2 \%$ plastic deformation was indicated by the shift in open circuit potential (OCP) values in the slow strain rate tensile (SSRT) measurements, while the MAO+PLGA composite coating provided effective protection of over $10 \%$ plastic deformation. The ductile PLGA was thought to be an extra preventative coating for the stressed Mg alloy implant substances.
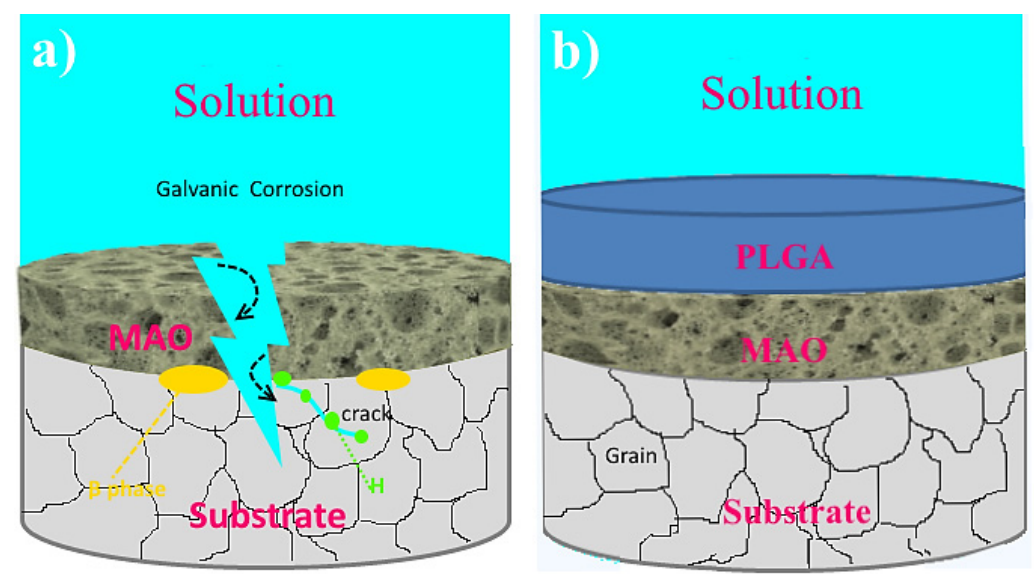

Figure 4. Schematic of the corrosion behavior for (a) MAO; (b) MAO+PLGA coated. Reprinted with permission from [43]; Copyright 2019 Elsevier.

Razzaghi et al. [44] studied the corrosion and biocompatibility properties of coating of the $\mathrm{Mg}-3 \mathrm{Zn}-0.5 \mathrm{Ag}-15 \mathrm{NiTi}$ nanocomposite substrate. PLGA/hardystonite (HT) was prepared on the surface of $\mathrm{Mg}$ alloy via a dip coating process. It was also discovered that the 10\% $(w / w)$ PLGA/HT composite coating has a better barrier effect than the lower PLGA concentrations. Furthermore, the $\mathrm{Ca} / \mathrm{P}$ ratio in in vitro bioactivity assessments following immersion in the SBF solution revealed that the coated specimen developed $70 \%$ more apatite than the uncoated specimens. In addition, electrochemical tests revealed that forming a PLGA/HT layer can effectively reduce the degradation rate of the sample. The $i_{\text {corr }}$ of the PLGA/HT composite-coated sample $\left(45.4 \mu \mathrm{A} / \mathrm{cm}^{2}\right)$ was found to be lower than that of the uncoated composite $\left(i_{\text {corr }}: 243.7 \mu \mathrm{A} / \mathrm{cm}^{2}\right)$. Furthermore, the decreased $i_{\text {corr }}$ could be due to the influence of polymer on the nanocomposite surface, which would prevent the magnesium-based electrode surface. Furthermore, the PLGA/HT film layer acts as a protective anodic layer, reducing environment penetration to the substrate. By incorporating HT into the PLGA, the coating's bonding strength to the substrate is increased, resulting in the formation of apatite on the surface of the specimen. To summarize, findings support the hypothesis that the use of PLGA/HT coatings on magnesium nanocomposite has a bright future as a biocompatible implant material. Shi et al. [45] showed evenly distributed pits on the whole surface of the PLGA polymer-coated layer after a short immersion time, as shown in Figure 5 [45]. The formation of bulges of various sizes might be caused by the evolution of $\mathrm{H}_{2}$ gas throughout the degradation process of $\mathrm{Mg}$ substrates. Micro-cavities began to develop in some areas on day 7 , and the evolution of microcracks was amplified considerably after 21 days, together with the bursting of gas pockets, implying that the polymeric layer began to erode. Finally, after 58 days, a great section of the polymeric layer 
was impaired, and defects with various sizes are detected, which is probably attributable to the erosion of the PLGA layer [45].

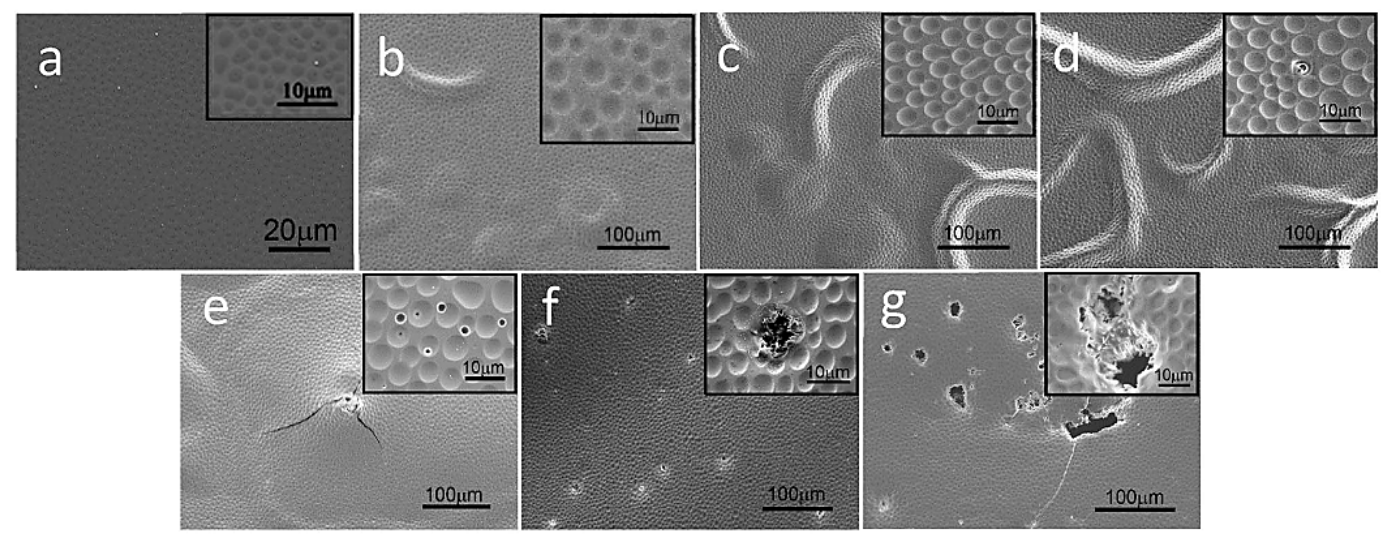

Figure 5. SEM micrographs of the coating surface during immersion test, (a) $0 \mathrm{~d}$, (b) $1 \mathrm{~d}$, (c) $4 \mathrm{~d}$, (d) $7 \mathrm{~d}$, (e) $21 \mathrm{~d}$, (f) $37 \mathrm{~d}$, and (g) 58 d of HF-pretreated Mg-Nd-Zn-Zr (F-JDBM) samples. Reprinted with permission from [45]; Copyright 2017 Elsevier.

\subsection{Polycaprolactone (PCL) Coated on Mg-Based Alloy}

In tissue engineering, polymeric materials are commonly used, and PCL is one of the most widely known that is Food and Drug Administration (FDA)-approved [7,18]. PCL, a biocompatible polymer with a low degradation rate and biodegradability, has been extensively investigated for biomedical applications. Additionally, it is processable through a variety of technologies due to its solubility in a vast variety of organic solvents, glass transition temperature, and low melting point [46]. Additionally, due to its ease of processing, nontoxicity, and high strain failure rate, PCL attracts great attention. As a result, it is used in a variety of medical applications [19]. Despite these benefits, a single PCL coating was used by a few scientists to lessen the rate of corrosion of magnesium alloys [18]. Yazdimamaghani et al. [47], using a powder metallurgy technique that included blending, pressing, and sintering to produce a Mg-based scaffold was applied to the surface of the scaffolds, which was followed by PCL. When compared to the uncoated scaffold, the PCLcoated Mg scaffolds showed significantly less degradation. Two different concentrations of coating material, $3 \%(w / v)$ PCL or $6 \%(w / v)$ PCL, were dissolved dichloromethane (DCM). They discovered that while the uncoated Mg scaffold degrades fully (100\% weight loss) after $72 \mathrm{~h}, \mathrm{Mg}$ scaffolds coated with $3 \%$ and $6 \%$ PCL just degrade $36 \%$ and $23 \%$, respectively. Their result showed as a biodegradable metal scaffold, PCL-coated Mg scaffolds may have a promising application in bone tissue engineering [47]. A biomedical coating should not only be corrosion resistant but also have excellent bioactivity, biocompatibility, and appropriateness for local pharmaceutical applications. These characteristics can be achieved by using the appropriate coating materials and methods [18]. Dai et al. [48] used the powder metallurgy method to create a Mg-6\%Zn- $10 \% \mathrm{Ca}_{3}\left(\mathrm{PO}_{4}\right)_{2}$ composite with a polycaprolactone (PCL) coating on the surface. The surface morphology, corrosion activity, and cytotoxicity characteristics of PCL coatings on the surface of a Mg- $6 \% \mathrm{Zn}-10 \% \mathrm{Ca}_{3}\left(\mathrm{PO}_{4}\right)_{2}$ composite were studied. The findings demonstrate that the PCL coating significantly improves the resistance to corrosion of $\mathrm{Mg}$ matrix composite samples. When compared to the uncoated, the PCL-coated specimens show the least rise in $\mathrm{pH}$ during degradation. The $\mathrm{pH}$ of the PCL-coated sample solution reached 9.6 after 14 days, while the $\mathrm{pH}$ of the control group was 10.7 [48]. In addition, the amount of evolved hydrogen in the PCL coating on the sample does not overpass $98.7 \mathrm{~mL} / \mathrm{cm}^{2}$ after 14 days, with a maximum losing weight of $3 \%$ primary mass, but the bare specimens show a substantial gain in hydrogen evolution and a weight loss of $10 \%$ of their primary mass. Against L-929 cells, cytotoxicity tests show that the $\mathrm{Mg}-6 \% \mathrm{Zn}-10 \% \mathrm{Ca}_{3}\left(\mathrm{PO}_{4}\right)_{2}$ with PCL coating is low in toxicity and has a rapid growth rate compared with the uncoated composites [48]. 
In another study, Saberi et al. [19] investigated the corrosion activity and biological properties of a polycaprolactone/bredigite (Bre) composite coating on a biodegradable $\mathrm{Mg}-\mathrm{Zn}-\mathrm{Ca}-\mathrm{GNP}$ nanocomposite, as shown in Figure 6 [19]. It was discovered that the PCL coating has a significant impact on corrosion properties. In addition, the PCL-10Br sample has a higher corrosion potential than the other specimens, indicating that this sample has a lower thermodynamic affinity to corrode. In addition, the lower anodic and cathodic slopes in the coated sample loaded with Bre indicate that the anodic and cathodic reaction kinetics is slower in the coated specimen loaded with Bre than in the others. The PCL coating comprising bredigite was found to have a beneficial impact on cell viability and adhesion. Tests revealed that increasing the amount of bredigite particles significantly improved the proliferation and growth of the MG-63 cell line. The MTT assay revealed that increasing bredigite particles improved cell viability over all time intervals. From this perspective, Bakhsheshi-Rad et al. [49] studied the corrosion and mechanical performance of a double-layered $\mathrm{Al} / \mathrm{PCL}$ coating on $\mathrm{Mg}-\mathrm{Ca}-\mathrm{Bi}$ alloy. A thick outer interconnected pores PCL layer and a thin inner compact $\mathrm{Al}$ thin layer create the coating. Their findings showed that after immersion in $\mathrm{NaCl}$ solution, the compressive strength of $\mathrm{Al} / \mathrm{PCL}$ coating is substantially higher than that of Al-coated samples, but the $\mathrm{Al}$ thin layer had a stronger bonding strength of $25.6 \mathrm{MPa}$ than the $\mathrm{Al} / \mathrm{PCL}$ coating, which was only 8.1 MPa. Electrochemical testing revealed that the bi-layered Al/PCL coating significantly improved the $\mathrm{Mg}-\mathrm{Ca}-\mathrm{Bi}$ alloy's corrosion resistance. In another study [50], their group used a combination of atmospheric plasma spraying (APS) and dip-coating methods to create a triplex (NiCoCrAlHfYSi $/ \mathrm{Al}_{2} \mathrm{O}_{3}-13 \% \mathrm{TiO}_{2}$ ) $/ \mathrm{PCL}$ composite coating on $\mathrm{Mg}-1.2 \mathrm{Ca}$ alloy. The plasma fabricated layers are usually $40-50 \mu \mathrm{m}$ thick, while the top layer is $100-110 \mu \mathrm{m}$ thick and made of hydrophobic PCL. After 10 days of immersion in $3.5 \mathrm{wt} \% \mathrm{NaCl}$, their results showed that a composite coating containing a PCL layer had a high compressive strength. The PCL coating efficiently insulated the pores of under-layer coatings and kept corrosive media from entering the NiCoCrAlHfYSi $/ \mathrm{Al}_{2} \mathrm{O}_{3}-13 \% \mathrm{TiO}_{2}$ layer [50]. Their research also revealed that a PCL coating significantly improved the resistance to corrosion of the plasma coating on $\mathrm{Mg}$ alloy. After immersion in $\mathrm{NaCl}$ solutions, they found that the compressive strength of the plasma/polymer composite coating is greater than that of plasma-coated and bare specimens. On the other hand, the plasma/PCL coating had a lower bonding strength than the single-layer and dual-layer plasma coatings. Since the polymer coating would avoid direct contact between the $\mathrm{Mg}$ matrix and corrosive species, the plasma/PCL coating drastically enhanced the resistance to corrosion of $\mathrm{Mg}$ alloy. This was derived from the lower corrosion rate than uncoated $\mathrm{Mg}$ alloy. As a consequence, it serves as a barrier at the Mg substrate/plasma bond-coating interface, preventing the development of galvanic cells. Bakhsheshi-Rad et al. [51] also prepared a bi-layered nanostructured fluorine-doped hydroxyapatite-polycaprolactone (nFHA/PCL) composite layer on the Mg alloy surface, consisting of an inner layer of nFHA and an outer layer of PCL deposited by electrodeposition and dip coating. The nanoneedlelike microstructure in the FHA film occupied the porous PCL outer layer and formed a homogeneous nFHA/PCL film, with nFHA crystallite sizes of around 70-90 nm. During an immersion test, mechanical tests revealed that using nFHA as an inner layer in the PCL matrix improved compressive stress when compared to uncoated samples. The resistance to corrosion of this layer was substantially enhanced when compared to the uncoated sample, according to electrochemical measurements [51]. The creation of a dense and uniform nFHA coating, as well as the homogeneous PCL coatings with excellent barrier properties, are responsible for the enhancement of corrosion resistance. Nano-HA/PCL coatings with a thickness of about 45-55 $\mu \mathrm{m}$ were prepared on the surface of $\mathrm{Mg}-\mathrm{Ca}$ alloy using electrochemical deposition and dip-coating techniques [52]. According to their results, both the PCL- and nano HA/PCL-coated specimens had greater compressive strength than the bare sample. The nano HA/PCL composite coating demonstrated greater bonding strength and corrosion resistance than the PCL coating due to the integration of nano HA with the PCL-coated layer on the Magnesium alloy. Indeed, a double layer nano-HA/PCL 
composite coating can effectively postpone electrolyte and chloride ion penetration, thereby improving the protective features. Another study [53] prepared a hybrid dual coating consisting of a silicon $(\mathrm{Si})$ underlayer and a PCL over layer to decrease the corrosion current densities of Mg-based materials. In comparison to the silicon-physical vapor deposition (Si-PVD) underlayer, the Si/PCL layer is $1.2 \mu \mathrm{m}$ thick and contains spherical nanoparticles, whereas the PCL over layer is $75.2 \mu \mathrm{m}$ thick and contains a structure of the porous network. Interestingly, the outcomes demonstrate that the PCL coating can prevent the substrate from losing mechanical properties because of the creation of thin Si layers as an underlayer using the PVD process. Yuan et al. [54] used a combination of dipping and spinning to coat poly (trimethylene carbonate) (PTMC) and PCL on Mg alloy stents. The hybrid coating showed promising elasticity, flexibility, and the capability of extending the service life of the stent. Long-term mechanical load bearing and nontoxicity are also possible [41,54].

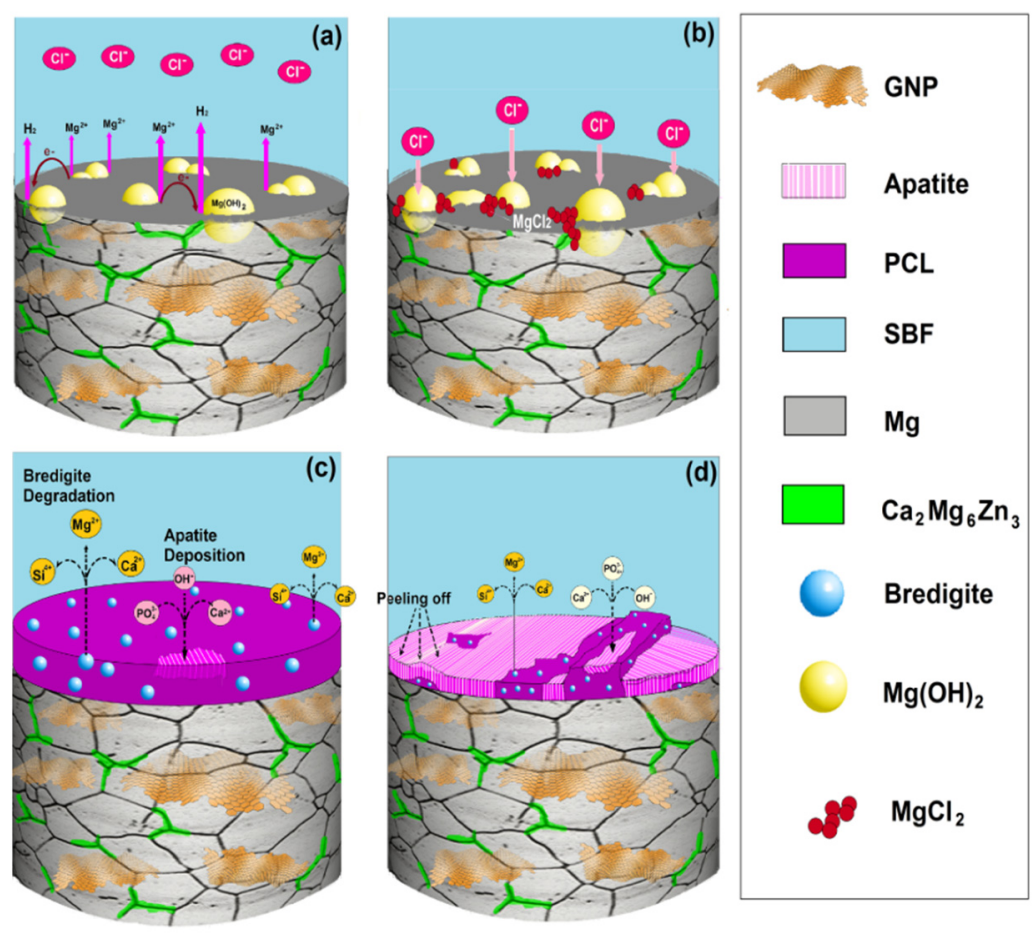

Figure 6. Schematic of the surface reaction with the SBF of $(\mathbf{a}, \mathbf{b})$ the bare sample and (c,d) PCLbredigite-coated Mg-based composite sample. Reprinted with permission from [19]; Copyright 2020 Elsevier.

Abdal-hay et al. [55] aimed to design a new porous hydroxyapatite-poly ( $\varepsilon$-caprolactone) hybrid composite based with high and low content of porosity on a Mg substrate. The coated specimens were made via a dip-coating approach to improve the implant's biocompatibility and bioactivity while also controlling rate of magnesium alloy degradation. According to the corrosion test finding, the neat PCL and the nHA-PCL composites demonstrated excellent corrosion resistance in the SBF. The $E_{\text {corr }}$ of composite film encapsulated with 5 and $10 \mathrm{wt} \%$ neat PCL and $5 \mathrm{wt} \%$ PCL-nHA were 200, 631, and $130 \mathrm{mV}$ higher, respectively, than those of a bare magnesium strip. At the same time, the corrosion current density $\left(i_{\text {corr }}\right)$ of the coated samples was lower than that of the bare samples. Based on the value of the $i_{c o r r}$ and $E_{c o r r}$, neat PCL and nHA-PCL composites could reduce corrosion rate. On the other hand, the composite coatings demonstrated more consistent and greater resistance to corrosion than neat PCL during the extended incubation period and were able to withstand extreme localized corrosion in body fluid. During immersion in SBF, uniform $\mathrm{CaP}$ nanomaterials develop quickly on the specimen surface, which was also used to assess the composite film's biocompatibility. The composite coatings performed better (almost 34\% higher) than the bare specimens in terms of mechanical integrity. Finally, their 
findings indicated that nHA combined with PCL composite coatings on Mg substrates could provide a good 3D platform for bone tissue cell adhesion and proliferation. This new as-synthesized nHA-PCL membrane on $\mathrm{Mg}$ biomaterials has the potential to be used as a future orthopedic material.

Table 1. Effects of synthetic polymer coatings and composite coatings parameters on $\mathrm{Mg}$-based material properties.

\begin{tabular}{|c|c|c|c|}
\hline Substrate & Coating & Effects & Ref. \\
\hline AZ91 & PLA & $\begin{array}{l}\text { Increases in the thickness of the PLA coating were found to improve } \\
\text { degradation resistance but resulted in poor adhesion }\end{array}$ & [32] \\
\hline AZ31 & $\mathrm{PLA} / \mathrm{CNs}$ & $\begin{array}{l}\text { The PLA-CNs nanocomposite coating improved substrate corrosion } \\
\text { resistance and increased hardness and mechanical properties }\end{array}$ & [56] \\
\hline $\mathrm{Mg}-3 \mathrm{Zn}-1 \mathrm{Ca}$ & $\begin{array}{l}\text { PLLA/GO- } \\
\text { AgNP }\end{array}$ & $\begin{array}{l}\text { The fibrous coating of PLLA/1GO-AgNPs demonstrates adequate } \\
\text { corrosion resistance, cytocompatibility, and antibacterial activity }\end{array}$ & [57] \\
\hline $\mathrm{Mg}-1 \mathrm{Ca}$ & $\begin{array}{l}\text { PLLA - AKT - } \\
\text { DOXY }\end{array}$ & $\begin{array}{c}\text { PLLA-AKT nanofiber coatings including low concentrations of DOXY } \\
\text { can be used to slow the degradation process and improve } \\
\text { antibacterial efficiency }\end{array}$ & [58] \\
\hline ZK60 & $\begin{array}{l}\text { PLGA-Gallic } \\
\text { Acid-PLGA }\end{array}$ & $\begin{array}{l}\text { The sandwich coating increased corrosion resistance while also } \\
\text { promoting endothelialization }\end{array}$ & [59] \\
\hline $\mathrm{Mg}-\mathrm{Sr}$ & PLGA $/ \mathrm{Ti}_{3} \mathrm{C}_{2}$ & $\begin{array}{l}\text { In comparison to the corrosion current density }\left(i_{\text {corr }}\right) \text { of the } \mathrm{Mg}-\mathrm{Sr} \text { alloy } \\
\left(7.13 \times 10^{-5} \mathrm{~A} / \mathrm{cm}^{2}\right) \text {, the adjusted samples }\left(\mathrm{Mg} / \mathrm{PLGA} / \mathrm{Ti}_{3} \mathrm{C}_{2}\right) \text { had a } \\
\text { corrosion current density of } 7.65 \times 10^{-9} \mathrm{~A} / \mathrm{cm}^{2} \text { that was approximately } \\
\text { four orders of magnitude lower. The } i_{\text {corr }} \text { of the modified samples } \\
\text { increased to } 3.48 \times 10^{-7} \mathrm{~A} / \mathrm{cm}^{2} \text { following near infrared } 808 \mathrm{~nm} \text { laser } \\
\text { irradiation. The mechanism is that local hyperthermia increased the } \\
\text { free volume of PLGA, and the resulting increase in intermolecular gap } \\
\text { improved electrolyte penetration }\end{array}$ & [60] \\
\hline $\mathrm{Mg}$ & PLA-PCL & $\begin{array}{l}\text { At } 37^{\circ} \mathrm{C} \text {, both polymer films enhanced the corrosion resistance of high } \\
\text { purity magnesium in m-SBF }\end{array}$ & [61] \\
\hline $\mathrm{Mg}$ & PCL & $\begin{array}{c}\text { Increased the coating thickness from } 0 \text { to } 13.31 \pm 0.36 \mu \mathrm{m} \text {, the volume } \\
\text { of hydrogen gas and the amount of magnesium ions, all of which are } \\
\text { measures of magnesium corrosion, decreased by nearly half, from } \\
0.57 \mathrm{~mL} / \mathrm{cm}^{2} / \text { day and } 0.55 \mathrm{mg} / \text { day to } 0.20 \mathrm{~mL} / \mathrm{cm}^{2} / \text { day and } \\
0.26 \mathrm{mg} / \text { day, respectively }\end{array}$ & [62] \\
\hline $\mathrm{Mg}$ & $\begin{array}{l}\text { ZnHA-Zeolite/ } \\
\text { PCL }\end{array}$ & $\begin{array}{l}\text { In vitro corrosion testing revealed that the composite coatings had } \\
\text { better corrosion resistance as compared to the bare Mg. The presence of } \\
\text { zinc in the coating allowed zinc-doped hydroxyapatite-zeolite } \\
\text { (ZnHA-Zeo) surfaces to reduce the viability of adhered bacteria } \\
\text { colonies when compared to HA-Zeo }\end{array}$ & [63] \\
\hline $\mathrm{Mg}$ & PCL/HA & $\begin{array}{l}\text { The corrosion resistance of the PCL/HA film was significantly higher } \\
\left(8720 \Omega \cdot \mathrm{cm}^{2}\right) \text { than that of the uncoated sample }\left(1562 \Omega \cdot \mathrm{cm}^{2}\right) \text {. However, } \\
\text { as compared to PCL and PCL/HA composite film with low HA content, } \\
\text { the PCL coating with high HA has lower corrosion resistance because } \\
\text { the agglomerate particles in the coating with a high HA amount did not } \\
\text { form a uniform and continuous film that can protect the substrate } \\
\text { from degradation }\end{array}$ & [64] \\
\hline $\begin{array}{c}\mathrm{Mg}-6 \% \mathrm{Zn}- \\
10 \% \mathrm{Ca}_{3}\left(\mathrm{PO}_{4}\right)_{2}\end{array}$ & PCL & $\begin{array}{l}\text { As compared to the uncoated specimen, the PCL-coated magnesium } \\
\text { matrix composite experiences the least rise in } \mathrm{pH} \text {, release of hydrogen, } \\
\text { and weight loss during in vitro degradation }\end{array}$ & [48] \\
\hline AZ31 & PEO/PCL & $\begin{array}{l}\text { Improved corrosion resistance; additionally, the PEO/PCL composite } \\
\text { coating was more suitable for cell adhesion and proliferation than the } \\
\text { AZ31 alloy and PEO coating. }\end{array}$ & [65] \\
\hline ZK60 & $\mathrm{MgF}_{2} / \mathrm{PCL}$ & $\begin{array}{l}\text { In vitro corrosion resistance, cell viability, cell adhesion, and cell } \\
\text { proliferation improved }\end{array}$ & [66] \\
\hline $\mathrm{Mg}-1.2 \mathrm{Ca}-2 \mathrm{Zn}$ & PCL/OCP/HA & $\begin{array}{l}\text { Improvement of corrosion resistance; after composite coating, the } \\
\text { corrosion current densities of } \mathrm{Mg} \text { alloy decreased significantly from } \\
\qquad 211.6 \text { to } 0.059 \mu \mathrm{A} / \mathrm{cm}^{2}\end{array}$ & [67] \\
\hline
\end{tabular}

PLA: Polylactic acid, CNs: Cellulose nanocomposite, Mg: Magnesium, Ca: Calcium, Zn: Zinc, GO: Graphene oxide, AgNP: Silver nanoparticle, AKT: Akermanite, DOXY: Doxycycline, PLGA: Poly(lactide-co-glycolic) acid, Sr: Strontium, $\mathrm{Ti}_{3} \mathrm{C}_{2}$ : Titanium carbide, PCL: Polycaprolactone, $i_{\text {corr }}$ : Corrosion current density, m-SBF: Modified simulated body fluid, ZnHA: Zinc-doped hydroxyapatite, Zeo: Zeolite, HA: Hydroxyapatite, PEO: Plasma electrolytic oxidation, $\mathrm{MgF}_{2}$ : Magnesium fluoride, OCP: Octacalcium phosphate. 


\section{Natural Polymer Coatings}

\subsection{Chitosan (CS) Coated on Mg-Based Alloy}

Chitosan, a chitin deacetylated derivative, is an inherent biopolymer with a vast variety of biological characteristics, which include good biodegradability, bioactivity, antimicrobial properties, and osteogenesis, making that useful in medical and industrial applications [68]. Liangjian et al. [69] researched the degradation activity of a magnesiumbased composite containing a chitosan coating in SBF. The corrosion rate, released metal ion concentration, and $\mathrm{pH}$ amounts of the composite with chitosan coating in SBF all were less than those of the bare $\mathrm{Mg}$ composite. The magnesium ion concentration in the uncoated specimen increased quickly from $5.11 \times 10^{-3}$ to $14.60 \times 10^{-3} \mathrm{~mol} / \mathrm{L}$ in less than 1 day, after which it remained relatively constant at around $15 \times 10^{-3} \mathrm{~mol} / \mathrm{L}$ after 30 days. The amount of $\mathrm{Mg}$ ion extracted from the specimen with chitosan coating was a little less than the bare sample [69]. After 30 days of immersion, the magnesium ion concentration was less than $4 \times 10^{-3} \mathrm{~mol} / \mathrm{L}$. With a toxic rating of zero, the sample with chitosan coating passed the in vitro cytotoxicity test, indicating that it is suitable for biomedical applications. The chitosan coating was a corrosion-resistant film that reduces the implant composite's hydrogen evolution, thus reducing the corrosion products' damage to the $\mathrm{Mg}$ composite as a biomedical implant. Table 2 shows effects of natural polymer and composite coatings parameters on $\mathrm{Mg}$ properties.

Hahn et al. [68] used aerosol deposition (AD) to prepare highly dense HA/chitosan (CS) film on $\mathrm{Mg}$ alloy to escalate its anticorrosion property and cell response. Coatings with adhesion strengths of 24.6-27.7 MPa were obtained, and the $E_{\text {corr }}$ values of the HA/CS coatings were shifted by $132-164 \mathrm{mV}$ toward more positive potentials depending on the content of chitosan applied to the coating, implying that the coatings are more corrosion resistant. In addition, the HA coating's corrosion current density $\left(i_{\text {corr }}\right)$ was observed to be more than two orders of magnitude less than the Mg alloy, implying that the HA coating improved the AZ31 Mg alloy's corrosion resistance. The $i_{\text {corr }}$ amount of the coatings improved as the content of chitosan integrated into the coating enhanced, but the $i_{\text {corr }}$ values of the film remained lower than that of $\mathrm{Mg}$ alloy. Eventually, polarization curves demonstrated that the coating applied on the AZ31 Mg alloy significantly reduced the degradation rate, despite the encapsulation of CS into the coating somewhat lowering the HA coating's corrosion resistance. As the CS concentration enhances, the composite coatings' corrosion resistance decreases, which is due to the chitosan's lower corrosion resistance compared to the HA ceramics. Simultaneously, HA coating and chitosan incorporation into the coating enhanced the alloy's biocompatibility.

Heise et al. [70] evaluated the electrochemical properties of Mg alloy with CS-bioactive glass (BG) coating in Dulbecco's Modified Eagle Medium (DMEM). A chitosan-BG mixture was found to have a positive zeta potential $(+42 \mathrm{mV})$ in a stable region. The coated sample had a higher impedance than the uncoated sample, according to the electrochemical analysis. Höhlinger et al. [71] investigated the protein effect on the degradation rate of $\mathrm{Mg}$ alloys coated with CS-BG. Electrophoretic-coated magnesium alloy was immersed in DMEM that lacked fetal bovine serum (FBS). When compared to the double layer-coated sample, no considerable mass loss was seen in the Mg alloy after immersion in 3 and 7 days compared to $\approx 2700 \mathrm{Ohm} \cdot \mathrm{cm}^{2}$ in the presence of FBS in DMEM. However, after 7 days, a significant shift was detected in the sample with CS-BG coating [72]. Bakhsheshi-Rad et al. [73] investigated the corrosion and antibacterial performance of $\mathrm{Mg}-\mathrm{Zn}-\mathrm{Ca}$ alloy coated with CS nanofibers containing silver sulfadiazine (AgSD) multiwall carbon nanotubes (MWCNTs) for bioimplants. Since bacterial growth is limited by the released $\mathrm{Ag}^{+}$ ions, chitosan nanofibers with AgSD-MWCNTs can significantly inhibit the growth and infiltration of Escherichia coli and Staphylococcus aureus, according to the antibacterial activity result. In this case, when Ag and SD ions enter bacteria, they cause intracellular protein and DNA damage, leading to cell death. The CS/AgSD-MWCNT composite nanofiber coating protects the Magnesium alloy substrate from corrosive solutions while also increasing corrosion resistance. Jia et al. [74] prepared a $\mathrm{pH}$-sensitive degradable coating 
by encapsulating $\mathrm{CeO}_{2}$ nanofillers in cytocompatible chitosan on PEO-treated $\mathrm{Mg}$ alloy. Corrosion caused by $\mathrm{OH}$ would cause chitosan to release $\mathrm{CeO}_{2}$ to refurbish the defects with corrosion products containing $\mathrm{Ce}$ during the corrosion process. Likewise, Calado et al. [75] created a $\mathrm{CeO}_{2}$-doped siloxane-based coating, and the results showed that $\mathrm{CeO}_{2}$ nanofillers inhibited corrosion growth and improved the coating's corrosion resistance for a long period. Bahatibieke et al. [76] evaluated the degradation rate and cytocompatibility of anodic oxidation-silane-chitosan coated on $\mathrm{Mg}-4.0 \mathrm{Zn}-0.8 \mathrm{Sr}$ alloy for bone tissue engineering. According to their findings, the anodizing (AO)-silane (SA)-CS coating sample has a lower corrosion rate as well as good biological properties, such as normal platelet adhesion morphology and a lower hemolysis rate. Bakhsheshi-Rad et al. [77] investigated the corrosion and antibacterial properties of a PCL/CS/ZnO composite coating on the magnesium. The porous structure of the PCL/CS film, with a thickness of about 40-50 $\mu \mathrm{m}$, improved corrosion resistance by inhibiting the diffusion of corrosive ions into the $\mathrm{Mg}$ substrate and improved antibacterial performance to prevent orthopedic infections. According to Figure 7 [76], the shape of the platelet on the surface of CS-coated, and bare Mg alloy is roughly spherical, the pseudopodia is not clear, and the level of platelet activation is poor. However, AO and SA-coated specimens presented a high level of platelet activation with obvious pseudopodia shape [76].
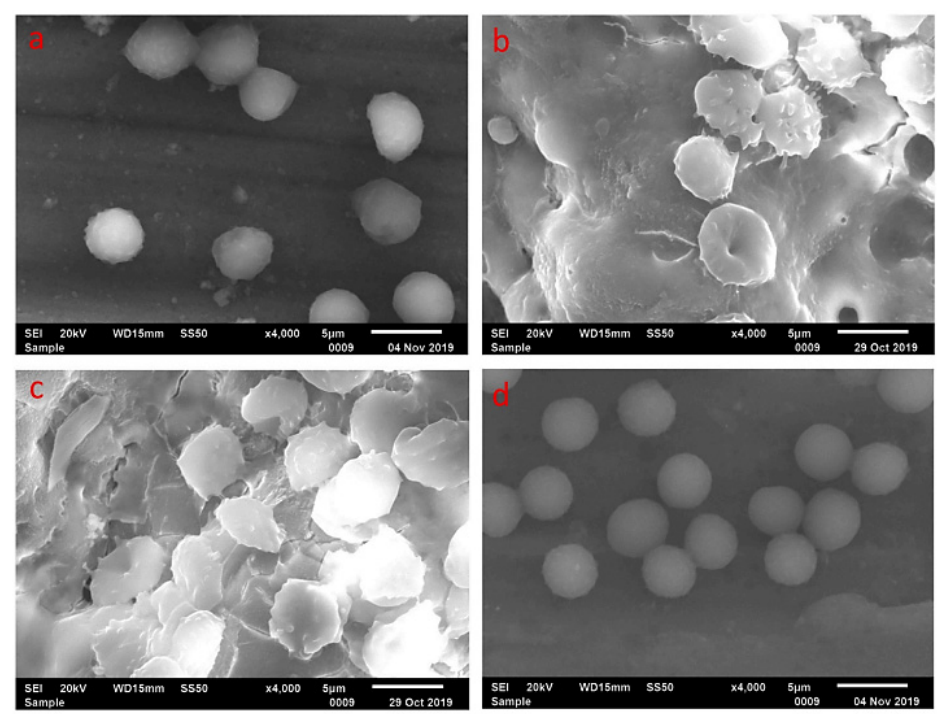

Figure 7. SEM images of platelets adhering to samples: (a) Mg alloy sample, (b) AO-coated sample, (c) AO-SA-coated sample, (d) AO-SA-CS-coated sample. Reprinted with permission from [76]; Copyright 2021 Elsevier.

\subsection{Collagen Coated on Mg-Based Alloy}

Collagen (Col) is the most widely available protein in the extracellular matrix, providing adhesion sites for cell attachment and migration. In the regeneration and healing of damaged tissues, collagen has superior biocompatibility and biodegradability. Collagen coating can be applied to Ti and Mg alloys, according to reports. In cell culture experiments, collagen-coated $\mathrm{Ti}$ and $\mathrm{Mg}$ alloys can induce cell proliferation and osteoblast phenotype expression [78]. In similar study, Park et al. [79] investigated the use of collagen film/fiber coating on $\mathrm{Mg}$ alloy stents to increase corrosion resistance and biocompatibility. The corrosion rate of dip-coated magnesium and bare magnesium is higher than the corrosion rate of electrospun collagen-coated magnesium, as shown in Table 3. Electrospinning a fiber coating is more effective on AZ31 magnesium alloy than dip coating. This result was primarily due to the high applied voltage during electrospinning, which allows for efficient collagen adhesion on the surface of alloy disk. The open morphology of electrospun fibers on the alloy surface could improve implant biocompatibility while also diminishing $\mathrm{Mg}$ ion release rates, allowing enough time for bone regeneration and bone growth. In 
another research study, Córdoba et al. [80] investigated the creation of bi-layered silane$\mathrm{TiO}_{2}$ biopolymer coatings on magnesium AZ31 and ZE41 alloys for bone regeneration fields. The $\mathrm{Mg}$ alloys were effectively protected from corrosion by the hybrid silane- $-\mathrm{TiO}_{2}$ coating. Top layers of collagen and chitosan polymers were also used to functionalize the silane- $\mathrm{TiO}_{2}$ coating to improve biocompatibility. The existence of biopolymers had a significant impact on the composition of both materials' corrosion products, according to the results [80]. While collagen or chitosan was present, carbonated components such as $\mathrm{MgCO}_{3}$ and $\mathrm{CaCO}_{3}$ formed as corrosion products, enhancing the corrosion resistance of $\mathrm{Mg}$ alloys over longer immersion periods (21 days) [80]. The biopolymer layer offered more corrosion resistance than the silane- $\mathrm{TiO}_{2}$ coating alone, according to EIS results. In their examination, $\mathrm{Mg}$ implants coated with the bi-layered systems could prevent $\mathrm{H}_{2}$ gas evolution. Their findings showed that bi-layered silane-based coatings with collagen and chitosan are being developed as a viable method for functionalizing AZ31 and ZE41 alloys for improved biocompatibility. In this respect, Guo et al. [81] improved the biocompatibility and biocorrosion resistance of magnesium alloys by successfully fabricating a composite coating on the surface consisting of calcium phosphate $(\mathrm{CaP})$ and collagen $(\mathrm{Col})$ via chemical conversion and dip-coating methods. The collagen coating effectively sealed the $\mathrm{CaP}$ coating's cracks and pores, greatly improving corrosion resistance. The polarization curves of the $\mathrm{CaP}$ and $\mathrm{CaP} / \mathrm{Col}$ coatings were significantly more positive than those of the $\mathrm{Mg}$ alloy (1.422 and 1.23 V, respectively) [81]. Furthermore, the $\mathrm{CaP} / \mathrm{Col}$ coating had a lower $i_{\text {corr }}\left(0.87 \mu \mathrm{A} \cdot \mathrm{cm}^{-2}\right)$ than the CaP coating, indicating that the $\mathrm{CaP} / \mathrm{Col}$ coating can protect the $\mathrm{Mg}$ alloy better. Furthermore, the $\mathrm{CaP} / \mathrm{Col}$ coating had a composition similar to bone, promoting osteoblast adhesion, proliferation, and differentiation more efficiently, demonstrating excellent biocompatibility and biosafety. According to their findings, the $\mathrm{CaP} / \mathrm{Col}$ coating can protect $\mathrm{Mg}$ alloy from rapid degradation, improve biocompatibility and osteoinductivity, and thus be a promising candidate for orthopedic implant applications. Barbeck et al. [82] fabricated a new biodegradable hydrofluoric acid (HF)-treated $\mathrm{Mg}$ mesh in a native collagen membrane for stable volume situations, which has great bioactivity and cytocompatibility but needs more research [82,83]. Guo et al. [84] investigated the electrochemical polarization and impedance (Nyquist and Bode plots) behavior of Mg alloy, polydopamine (PDA)/dicalcium phosphate dihydrate (DCPD), collagen (Col) coatings, and their results demonstrated a lower $i_{\text {corr }}$ and noticeably higher impedance than the bare sample (Figure 8) [84], implying that the PDA/DCPD/Col composite coating provided high protection from substrate against corrosion attack.

(a)

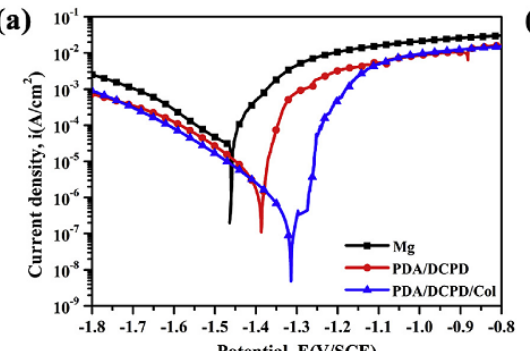

(c)

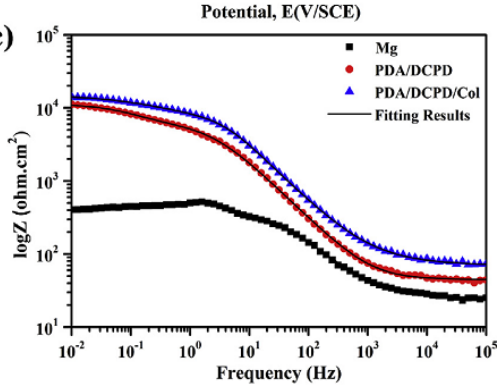

(b)

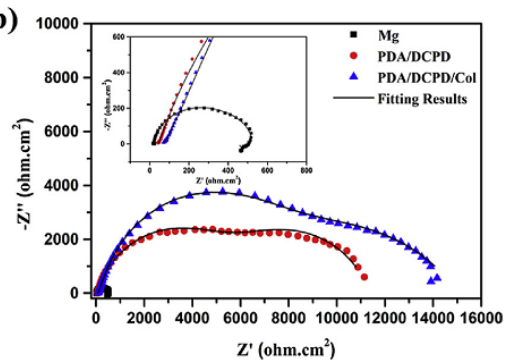

(d)

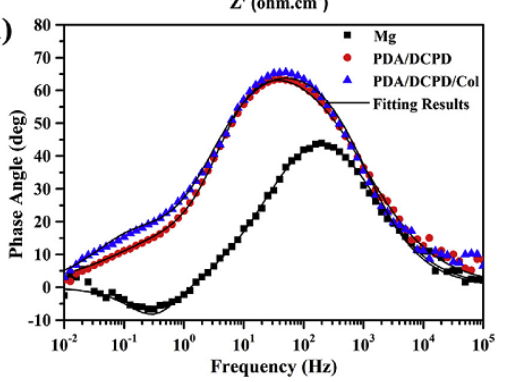

Figure 8. Electrochemical corrosion behavior of different samples: (a) Polarization curves; (b) Nyquist plots; (c) Bode plots of log $|\mathrm{Z}|$ and (d) Bode plot of phase angle. Reprinted with permission from [84]; Copyright 2020 Elsevier. 


\subsection{Gelatin Coated on Mg-Based Alloy}

As a result of its biological origin, biocompatibility, immunogenicity, and bioactivity, gelatin (Gel), a collagen derivative, has recently been used in a wide range of biomedical applications, including drug delivery, tissue engineering, wound bands, and medical care devices. Additionally, gelatin enhances the adhesion, migration, and proliferation of a wide variety of cells [85]. Jafarzadeh et al. [86] used the dip-coating technique to deposit a gelatin $/ \mathrm{Si}-\mathrm{Mg}-\mathrm{FA}$ nanocomposite coating on AZ31 Mg alloy specimens. In an electrolytic aqueous solution containing $\mathrm{NaOH}, \mathrm{Na}_{2} \mathrm{SiO}_{3}$, and $\mathrm{KOH}$, the anodized coating was also developed on the AZ31 Mg alloy. The surface of a nanocomposite coating with a homogeneous distribution of nanoparticles in the gelatin matrix was dense, crack-free, well compacted, and uniform, while the surface of an anodized layer was comparatively coarse due to defects, microcracks, and micropores. The ability of nanocomposite-coated specimens to form bone-like apatite is demonstrated by immersion testing in SBF solution [86]. Table 3 summarizes the results of the corrosion properties of polymer-coated and composite coated $\mathrm{Mg}$-based composites and $\mathrm{Mg}$ alloys under various corrosion media, and measurement methods. In contrast to uncoated and anodized specimens, the electrochemical tests revealed that the nano-composite coating plays a more effective role in improving corrosion resistance. As opposed to the uncoated specimen, the formation of an anodized and nanocomposite coating results in a change in $E_{\text {corr }}$ to more positive values ( -1.68 to $-1.47 \mathrm{~V}$ ), while the corrosion current densities of the coated specimens are moved to a smaller amount $\left(2.98 \times 10^{-4}\right.$ to $\left.5.022 \times 10^{-5} \mathrm{~A} \cdot \mathrm{cm}^{-2}\right)$ compared to the uncoated counterpart, implying that the composite coating could regulate the corrosion rate of $\mathrm{Mg}$ alloys for orthopedic applications. Jothi et al. [85] fabricated polypyrrole/Gel coatings using anodization and electrodeposition methods to increase the corrosion resistance of AZ31 $\mathrm{Mg}$ substrates. The influence of anodization time and gelatin content on the corrosion resistance efficiency of coated AZ31 Mg substrates was thoroughly investigated via various characterization approaches. Surface and structural characterization tests were used to validate the influence of anodization period and gelatin inclusion on the surface characteristics of polymeric films on $\mathrm{Mg}$ substrates. In vitro corrosion test results confirmed that the $R_{c t}$ value of polypyrrole/gelatin $1 \mathrm{wt} \%$ (PPy/Gel2) $\left(6.74 \times 10^{5} \Omega \cdot \mathrm{cm}^{2}\right)$ is four times that of pure PPy-40 min anodization time $\left(1.91 \times 10^{5} \Omega \cdot \mathrm{cm}^{2}\right)$ and one order of magnitude higher than that of neat PPy $\left(2.31 \times 10^{4} \Omega \cdot \mathrm{cm}^{2}\right)$, suggesting that the anodized AZ31 Mg substrate with coating portrayed the greatest surface protective employment toward corrosion [85]. Based on scanning electrochemical microscopy (SECM), the level of hydrogen released is considerably diminished in the existence of an anodization layer prior to coating and gel inclusion into the PPy coating. According to their findings, the preparation of a composite coating containing anodization film and a polymeric (PPy/Gel) layer enhanced the corrosion resistance and biodegradability of AZ31 alloys in SBF environments. Corrosion studies by Akram et al. [87] revealed that the Mg-Si-Sr alloy containing a chitosan-gel-BG coating had a significantly reduced corrosion rate of $0.08 \mathrm{~mm} /$ year. Qi et al. [88] used electrophoretic deposition (EPD) to create a gelatin nanospheres/chitosan (GelNs/CS) composite coating on a Mg alloy substrate with simvastatin (SIM) loaded into the GelNs. According to their findings, SIM-loaded GelNs/CS composite coatings were capable of improving the corrosion resistance and enhanced the osteogenic differentiation of the WE43. Over the course of 28 days, the SIM-loaded coating on the Mg alloy released simvastatin continuously.

\subsection{Silk Fibroin Coated on Mg-Based Alloy}

As a result of its robust mechanical characteristic, environmental stability, and biodegradability, silk fibroin (SF), a natural organic macromolecular material derived from mulberry silkworms, is actually broadly employed in the manufacturing of numerous physiological materials. The outstanding anticorrosion property, cell response, and adjustable degradation rate of SF were likewise exhibited in biological usage, including the synthesis of thin films, scaffolds, and other kinds of matrices. Therefore, coating Mg alloys 
with SF to produce a hurdle among organic macromolecules and inorganic metal materials is new and achievable, which decreased the degradation of magnesium alloys [89]. Wang et al. [89] effectively synthesized an SF film with a hardness of $0.531 \mathrm{GPa}$ onto a 3-amino-propyltriethoxysilane (APTES) pre-coated Mg alloy. A dense film with no crack at the interface coating/underlayer was observed. The amino group on the APTES-modified $\mathrm{Mg}$ alloy surface is generating bonds with the protective SF film. According to degradation tests, the SF film is able to offer long-term protectiveness from $\mathrm{Mg}$ alloy underlayer and boost anticorrosion property in SBF. Moreover, it was found that the SF-treated Mg alloy was more bioactive in comparison with the bare sample.

$\mathrm{Xu}$ et al. [90] used SF in order to produce a coating of stent with the aim of escalating the anticorrosion property as well as elevating the cell response and sirolimus (SRL) drug release system of the Mg alloy stent. Following the SF coating of the stent, the SF layer was ethanol-treated, which postponed SRL evolution from the SF film. The SF film protects the underlayer from severe corrosion attack; thus, the stent's mechanical integrity improved when exposed to the SBF. The corrosion rate of the HF-treated Mg stents diminished from $30 \%$ to $7 \%$ after 14 days [90]. The HF treatment elevated the anticorrosion property of the $\mathrm{Mg}$ stent by creation of $\mathrm{MgF}_{2}$ and $\mathrm{Mg}(\mathrm{OH})_{2}$ barrier films. Due to its distinctive composition, which consists of both hydrophobic and hydrophilic blocks, the SF film fails to completely protect toward water attack via the oxide layer. The SF film exhibited remarkable cytocompatibility. The SF is likely to substitute traditional biodegradable polymers in bioresorbable stents.

Fang et al. [91] developed silk fibroin (SF)/sodium alginate (SA) composite coatings on biodegradable $\mathrm{Mg}$ alloys that were activated with vacuum ultraviolet ozone $\left(\mathrm{VUV} / \mathrm{O}_{3}\right)$ to improve the mechanical characteristics and attachment force of protective films. When the mass ratio of SF/SA was 70/30, the attachment force of the coating was considerably increased, showing three times those of pure SF or pure SA coatings. The increased surface hydrophilicity of the $\mathrm{Mg}$ alloy, the solid chemical bonds at the interface, and the intermolecular reactions between the SA and SF molecules were the main reasons for this superiority. Meanwhile, the addition of SA significantly increases the Mg alloy coated corrosion resistance, causing a reaction layer to form in the corrosion procedure. In a similar study, Wang et al. [92] used a natural silk fibroin protein coating to enhance the biocompatibility and control corrosion resistance of a $\mathrm{Mg}-\mathrm{Zn}-\mathrm{Ca}$ alloy. Their result indicated that the $\mathrm{SF}$ film provided corrosion-resistant protection as a biological barrier, effectively delaying the degradation of the $\mathrm{Mg}-\mathrm{Zn}-\mathrm{Ca}$ alloy substrate. According to Figure 9 [92], the cells on the bare $\mathrm{Mg}-\mathrm{Zn}-\mathrm{Ca}$ samples had a spherical morphology and remained round throughout the incubation period. The cells on the surface of the coated samples containing silk fibroin and $\mathrm{SF}-\mathrm{Mg}-\mathrm{Zn}-\mathrm{Ca}\left(\mathrm{VUV} / \mathrm{O}_{3}\right)$ were almost stretched out and displayed enhanced cellular spreading and adhesion abilities. Cell numbers and viability were lower in bare $\mathrm{Mg}-\mathrm{Zn}-\mathrm{Ca}$ alloy samples at all intervals of time compared to samples with coating, indicating that the proliferation of cells on the $\mathrm{Mg}-\mathrm{Zn}-\mathrm{Ca}$ alloy surface is poor. Xiong et al. [93] used spin coating to create $\mathrm{Ca}, \mathrm{Sr} / \mathrm{P}$ silk fibroin composite coatings on fluoride-pretreated $\mathrm{Mg}-1 \mathrm{Ca}$ to increase the corrosion resistance, bioactivity, and osteogenic differentiation potential. The addition of $\mathrm{Ca}, \mathrm{Sr} / \mathrm{P}$ to the films changed the secondary structures of silk fibroin. In vitro immersion tests and electrochemical experiments showed that the composite films could increase substrate corrosion resistance and act as an effective barrier. Combining the results of two measurements (cytocompatibility and cell adhesion), it was discovered that silk fibroin-coated $\mathrm{Mg}-1 \mathrm{Ca}$ alloy samples have better cell proliferation than two groups of $\mathrm{Mg}-1 \mathrm{Ca}$ alloy and fluoride-treated $\mathrm{Mg}-1 \mathrm{Ca}$ alloy; this is due to the biocompatibility of silk fibroin. 


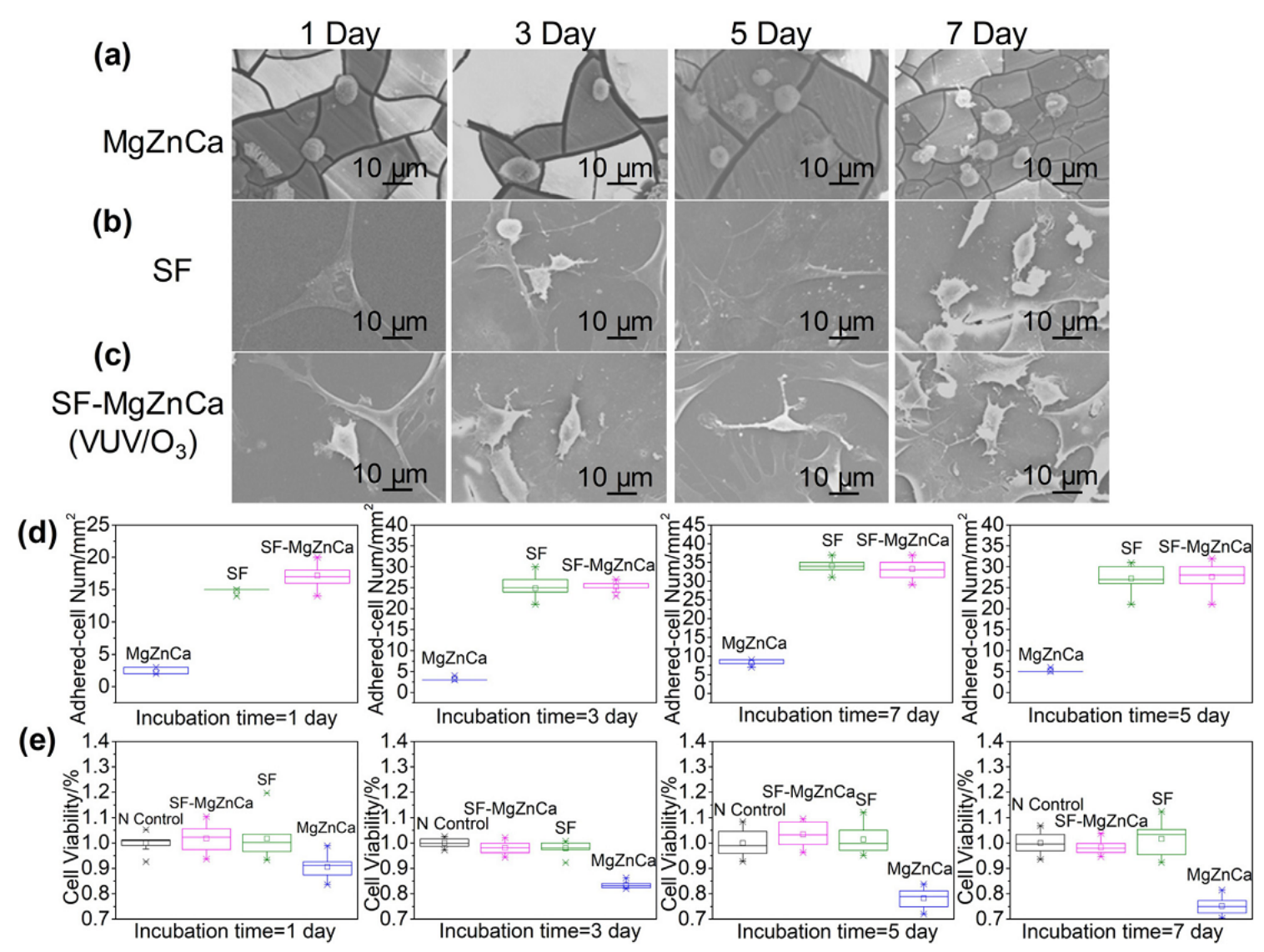

Figure 9. Morphologies of adhered cells on 1,3,5, and 7 days on the surface of (a) Bare MgZnCa, (b) Bare silk fibroin, and (c) SF-MgZnCa (VUV/O $/ 3$ ); (d) Adhered cell numbers per 1000× field and (e) Cell viability of BMSCs indirectly cocultured with bare $\mathrm{MgZnCa}$, bare silk fibroin, and SF-MgZnCa $\left(\mathrm{VUV} / \mathrm{O}_{3}\right)$. Reprinted with permission from [92]; Copyright 2019 Elsevier.

Table 2. Effects of natural polymer coatings and composite coatings parameters on Mg-based material properties.

\begin{tabular}{|c|c|c|c|}
\hline Substrate & Coating & Effects & Ref. \\
\hline $\mathrm{Mg}-\mathrm{Zn}-\mathrm{Ca}$ & Chitosan/MAO & $\begin{array}{l}\text { At the same time, the corrosion current density was } \\
\text { decreased by nearly } 3 \text { orders compared with that of bare alloy }\end{array}$ & [94] \\
\hline AZ91 & $\begin{array}{l}\text { Chitosan-bioactive } \\
\text { glass }(\mathrm{BG})\end{array}$ & $\begin{array}{l}\text { BG concentration of } 0.4 \mathrm{~g} / \mathrm{L} \text { in } \mathrm{CS}-\mathrm{BG} \text { coatings showed the } \\
\text { best corrosion resistance and bioactivity }\end{array}$ & [95] \\
\hline AZ91 & Baghdadite/ PCL/chitosan & $\begin{array}{l}\text { Improved the corrosion resistance with } 3 \text { wt } \% \text { baghdadite } \\
\text { and increased the roughness }\end{array}$ & [96] \\
\hline $\mathrm{Mg}-6 \% \mathrm{Zn}-10 \% \mathrm{Ca}_{3}\left(\mathrm{PO}_{4}\right)_{2}$ & Chitosan & $\begin{array}{c}\text { Improved the corrosion resistance and reduced hydrogen } \\
\text { release from } \mathrm{Mg} \text {-based substrate }\end{array}$ & [97] \\
\hline $\mathrm{Mg}$ & $\begin{array}{l}\text { Chitosan/heparinized } \\
\text { graphene oxide }\end{array}$ & $\begin{array}{l}\text { Improvement in the corrosion resistance and biocompatibility } \\
\text { of the } \mathrm{Mg} \text { substrate }\end{array}$ & [98] \\
\hline AZ31 and ZE41 & $\mathrm{TiO}_{2} /$ collagen & $\begin{array}{l}\text { Improvement in the cell response and viability and ability to } \\
\text { control degradation rate of } \mathrm{Mg} \text { alloys in the long term }\end{array}$ & [99] \\
\hline AZ60 & PDA/DCPD/Collagen & $\begin{array}{l}\text { Enhanced cytocompatibility, osteogenic differentiation ability, } \\
\text { and corrosion resistance of AZ60 substrate }\end{array}$ & [84] \\
\hline AZ91D & Gelatin-chitosan & $\begin{array}{l}\text { Coated alloy presented better corrosion resistance so as to } \\
\text { promote a self-healing performance }\end{array}$ & [100] \\
\hline $\mathrm{Mg}-3 \mathrm{Zn}-0.5 \mathrm{Sr}$ & $\begin{array}{c}\text { Chitosan } \\
\left(\mathrm{TiO}_{2}\right) \text {-heparin/MAO }\end{array}$ & $\begin{array}{l}\text { Layer by layer assembled films effectively sealed the pores } \\
\text { in MAO layer, thus increases the corrosion resistance of } \\
\text { Mg alloy substrate }\end{array}$ & {$[101]$} \\
\hline $\mathrm{Mg}-\mathrm{Zn}-\mathrm{Ca}$ & Silk fibroin & $\begin{array}{l}\text { Formation of silk fibroin film improved the corrosion } \\
\text { resistance of the } \mathrm{Mg}-\mathrm{Zn}-\mathrm{Ca} \text { underlayer }\end{array}$ & [102] \\
\hline $\mathrm{Mg}-\mathrm{Zn}-\mathrm{Y}-\mathrm{Nd}-\mathrm{Zr}$ & $\begin{array}{l}\text { Hydroxyapatite/ } \\
\text { silk fibroin }\end{array}$ & $\begin{array}{c}\text { Improvement of anticorrosion ability and good efficacy in } \\
\text { guidance of cell attachment and alignment by preparation of } \\
\text { hydroxyapatite/silk fibroin on } \mathrm{Mg} \text { alloy }\end{array}$ & [103] \\
\hline
\end{tabular}


Table 2. Cont.

\begin{tabular}{cccc}
\hline Substrate & Coating & Effects & Ref. \\
\hline $\mathrm{Mg}-1 \mathrm{Ca}$ & $\mathrm{Sr} /$ P-doped silk fibroin silk & $\begin{array}{c}\text { Improvement of corrosion resistance, biocompatibility, and } \\
\text { osteogenic potential }\end{array}$ & [93] \\
\hline $\mathrm{Mg}-1 \mathrm{Ca}$ & $\begin{array}{l}\text { Silk fibroin } \\
\text { and } \mathrm{K}_{3} \mathrm{PO}_{4}\end{array}$ & $\begin{array}{c}\text { Enhance in corrosion resistance, osteogenic activity, and } \\
\text { self-healing ability }\end{array}$ & [104] \\
\hline
\end{tabular}

MAO: Micro-arc oxidation, CS: Chitosan, BG: Bioactive glass, PCL: Polycaprolactone, Sr: Strontium, PDA: Polydopamine, DCPD: Dicalcium phosphate dihydrate, Nd: Neodymium, Y: Yttrium, Zr: Zirconium.

Table 3. Corrosion properties of polymer-coated and composite-coated Mg-based composites and Mg alloys.

\begin{tabular}{|c|c|c|c|c|c|c|}
\hline Substrate & Coating & Electrolyte & $\begin{array}{l}\text { Immersion Time } \\
\text { (min) }\end{array}$ & $E_{\text {corr }}(\mathrm{V} / \mathrm{SCE})$ & $\begin{array}{c}i_{\text {corr }} \\
\left(\mu \mathrm{A} / \mathrm{cm}^{2}\right)\end{array}$ & Ref. \\
\hline AZ31 & Uncoated & Hank's solution & 60 & -1.607 & 34.8 & [35] \\
\hline AZ31 & HA & Hank's solution & 60 & -1.453 & 17.6 & [35] \\
\hline AZ31 & $\mathrm{HA} / \mathrm{PCL}$ & Hank's solution & 60 & -1.399 & 5.98 & [35] \\
\hline AZ31 & $\mathrm{HA} / \mathrm{TiO}_{2} / \mathrm{PLA}$ & Hank's solution & 60 & -0.430 & $8.91 \times 10^{-4}$ & [35] \\
\hline AZ31 & Uncoated & SBF & 120 & -1.67 & 611.71 & [36] \\
\hline AZ31 & MAO & SBF & 120 & -1.57 & 66.32 & [36] \\
\hline AZ31 & PLA & SBF & 120 & -1.57 & 7.72 & [36] \\
\hline AZ31 & MAO-PLA & SBF & 120 & -1.50 & 1.83 & [36] \\
\hline Mg6Zn & Uncoated & $0.9 \% \mathrm{NaCl}$ & - & -1.46 & 26.5 & [42] \\
\hline Mg6Zn & $\% 2$ PLGA & $0.9 \% \mathrm{NaCl}$ & - & -1.44 & 0.085 & [42] \\
\hline Mg6Zn & $\% 4$ PLGA & $0.9 \% \mathrm{NaCl}$ & - & -1.36 & 0.097 & [42] \\
\hline $\mathrm{Mg}-4 \mathrm{Zn}-0.6 \mathrm{Zr}-0.4 \mathrm{Sr}$ & Uncoated & SBF & 30 & -1.66 & $1.95 \times 10^{2}$ & [43] \\
\hline $\mathrm{Mg}-4 \mathrm{Zn}-0.6 \mathrm{Zr}-0.4 \mathrm{Sr}$ & MAO & SBF & 30 & -1.57 & 1.87 & [43] \\
\hline $\mathrm{Mg}-4 \mathrm{Zn}-0.6 \mathrm{Zr}-0.4 \mathrm{Sr}$ & MAO+PLGA & SBF & 30 & -1.54 & $1.39 \times 10^{-1}$ & [43] \\
\hline $\mathrm{Mg}-4.98 \mathrm{Al}-0.29 \mathrm{Mn}$ & Uncoated & SBF & 20 & -1.340 & 103 & [55] \\
\hline $\mathrm{Mg}-4.98 \mathrm{Al}-0.29 \mathrm{Mn}$ & $5 \%$ PCL & SBF & 20 & -1.140 & 7.723 & [55] \\
\hline $\mathrm{Mg}-4.98 \mathrm{Al}-0.29 \mathrm{Mn}$ & $10 \%$ PCL & SBF & 20 & -0.709 & 1.721 & [55] \\
\hline $\mathrm{Mg}-4.98 \mathrm{Al}-0.29 \mathrm{Mn}$ & $\mathrm{PCL} / \mathrm{nHA}$ & SBF & 20 & -1.210 & 3.6 & [55] \\
\hline Mg-3Zn-1Ca-1GNP & Uncoated & SBF & 30 & -1.45 & 111.7 & [19] \\
\hline Mg-3Zn-1Ca-1GNP & PCL & SBF & 30 & -1.46 & 62.9 & [19] \\
\hline Mg-3Zn-1Ca-1GNP & $\mathrm{PCL} / 2.5 \mathrm{Br}$ & SBF & 30 & -1.30 & 31.11 & [19] \\
\hline Mg-3Zn-1Ca-1GNP & $\mathrm{PCL} / 5 \mathrm{Br}$ & SBF & 30 & -1.36 & 2.55 & [19] \\
\hline Mg-3Zn-1Ca-1GNP & $\mathrm{PCL} / 10 \mathrm{Br}$ & SBF & 30 & -1.15 & 0.45 & [19] \\
\hline AZ31 & HA & SBF & - & -1.569 & 4.765 & [68] \\
\hline AZ31 & HA-5\% Chitosan & SBF & - & -1.601 & 15.15 & [68] \\
\hline AZ31 & HA- $10 \%$ Chitosan & SBF & - & -1.581 & 31.44 & [68] \\
\hline AZ31 & HA- $20 \%$ Chitosan & SBF & - & -1.586 & 50.97 & [68] \\
\hline AZ31 & Uncoated & SBF & 60 & -1.68 & $2.98 \times 10^{2}$ & [86] \\
\hline AZ31 & Anodized coat & SBF & 60 & -1.59 & $1.071 \times 10^{2}$ & [86] \\
\hline AZ31 & Gelatin/Si-Mg-FA & SBF & 60 & -1.47 & 50.22 & [86] \\
\hline AZ31 & PPy & SBF & - & -1.480 & 8.251 & [85] \\
\hline AZ31 & $\begin{array}{l}\text { PPy-Anodization } \\
\text { (20 min) }\end{array}$ & SBF & - & -1.412 & 0.254 & [85] \\
\hline AZ31 & $\begin{array}{l}\text { PPy-Anodization } \\
\text { (40 min) }\end{array}$ & SBF & - & -1.394 & 0.124 & [85] \\
\hline AZ31 & $\begin{array}{l}\text { PPy-Anodization } \\
\text { (60 min) }\end{array}$ & SBF & - & -1.403 & 0.189 & [85] \\
\hline AZ31 & PPy-Gel0.5 & SBF & - & -1.325 & 0.092 & [85] \\
\hline
\end{tabular}


Table 3. Cont.

\begin{tabular}{|c|c|c|c|c|c|c|}
\hline Substrate & Coating & Electrolyte & $\begin{array}{c}\text { Immersion Time } \\
(\mathrm{min})\end{array}$ & $E_{\text {corr }}(\mathrm{V} / \mathrm{SCE})$ & $\begin{array}{c}i_{\text {corr }} \\
\left(\mu \mathrm{A} / \mathrm{cm}^{2}\right)\end{array}$ & Ref. \\
\hline AZ31 & PPy-Gel1 & SBF & - & -1.309 & 0.014 & [85] \\
\hline AZ31 & PPy-Gel2 & SBF & - & -1.315 & 0.054 & [85] \\
\hline $\mathrm{Mg}-1.5 \mathrm{Zn}-0.5 \mathrm{Ca}$ & Uncoated & SBF & - & -1.56 & $1.37 \times 10^{-2}$ & [89] \\
\hline $\mathrm{Mg}-1.5 \mathrm{Zn}-0.5 \mathrm{Ca}$ & APTES & SBF & - & -0.80 & $3.65 \times 10^{-2}$ & [89] \\
\hline MA8 & Uncoated & $3 \% \mathrm{NaCl}$ & - & -1.56 & 53 & [105] \\
\hline MA8 & $\mathrm{PEO}$ & $3 \% \mathrm{NaCl}$ & - & -1.50 & $7.8 \times 10^{-2}$ & [105] \\
\hline MA8 & $\begin{array}{c}\text { PEO+SPTFE } \\
\text { (single) }\end{array}$ & $3 \% \mathrm{NaCl}$ & - & -1.46 & $3.3 \times 10^{-2}$ & [105] \\
\hline MA8 & $\begin{array}{c}\text { PEO+SPTFE } \\
\text { (five-fold) }\end{array}$ & $3 \% \mathrm{NaCl}$ & - & -1.27 & $3.1 \times 10^{-3}$ & [105] \\
\hline
\end{tabular}

$E_{\text {corr }}$ : Corrosion potentials, $i_{\text {corr }}$ : Corrosion current density, PCL: Polycaprolactone, PLA: Polylactic acid, HA: Hydroxyapatite, SBF: Simulated body fluid, MAO: Micro-arc oxidation, PLGA: Poly(lactide-co-glycolic) acid, GNP: Graphene nano-platelet, Sr: Stontium, Br: Bredigite, FA: Fluorapatite, PPy: Polypyrrole, Gel: Gelatin, APTES: 3-amino-propyltriethoxysilane, SPTFE: Superdispersed polytetrafluoroethylene, PEO: Plasma electrolytic oxidation.

\section{Composite Polymer Coatings}

While polymeric coatings individually could not be enough to meet practical needs, integrating polymer coatings with ceramic particles is a promising way for certain application fields. Given the highly complex biological environment, composite coatings that integrate the characteristics of multiple coatings hold great promise. Even so, as the number of interfaces in composite coatings increases, adhesion strength not only between the substrate and coating, but also among layers, becomes more important [18]. Coatings which boost the surface features of different materials are made using the plasma electrolytic oxidation (PEO) process. This process can be used to protect magnesium alloys from corrosion. By using the PEO method to create coatings on a Mg alloys surface, one can significantly extend the field of their practical application. In the scanning probe experiment, electrochemical tests were used to investigate the trends in the creation of corrosion processes in the vicinity of an artificially produced defect in the PEO coating [39,65]. As a result, it was discovered that the corrosion procedure of a $\mathrm{Mg}$ alloy formed primarily at the interface of coating/substrate, i.e., beneath the protective film, resulting in $\mathrm{Mg}$ substrate corrosion and eventual interruption of the surface layer owing to its large corrosion activity in a corrosion medium containing chloride.

In view of this, the production of coating deposition methods that are not only corrosion-resistant but also have anti-wear and antifriction properties is critical, as this will greatly lessen the probability of mechanical damage of the specimens [105]. In this respect, Chen et al. [106] used a composite polymer coating to improve the resistance to corrosion of Mg-based implants. Poly( $\gamma$-glutamic acid)-g-7-amino-4-methylcoumarin/ hydroxyapatite ( $\gamma$-PGA-g-AMC/HA) composite nanoparticles were decorated on $\mathrm{Mg}$ surfaces using EPD in ethanol. Sample rods of bare Mg and coated Mg were inserted intramedullary into the New Zealand white rabbits' femora, and periodic radiography and post-autopsy histopathology were analyzed for each sample. The coating material appeared to have strong histocompatibility and osteoinductivity in vivo, according to the in vivo results [106]. Chen et al. [107] fabricated a $\mathrm{TiO}_{2} /$ polydopamine (PDA) composite coating on pure $\mathrm{Mg}$. The PDA layer was first covalently immobilized on $\mathrm{Mg}$, and then, via liquid phase deposition, $\mathrm{TiO}_{2}$ was deposited on it. The hybrid $\mathrm{TiO}_{2} / \mathrm{PDA}$-coated $\mathrm{Mg}$ reduced the in vitro corrosion current density and degradation rate (up to 21 days) in PBS much more than direct $\mathrm{TiO}_{2}$-coated and bare $\mathrm{Mg}$ [41]. A composite coating of PCL and copper-based metal-organic framework (MOF) modified with folic acid (FA) was created on the AZ31 Mg alloy. The corrosion resistance was greatly improved in electrochemical tests because the corrosion current density was greatly lowered. Copper ions were also gradually released from the composite coating, promoting osteoblastic cell growth and 
differentiation [108]. Rahimi et al. [109] used electro-spinning to create a nanofibrous composite coating incorporating chitosan and mineralized bone allograft (MBA) nano additions on AZ31 Mg alloy to improve the corrosion resistance and cytocompatibility in a biological environment. Both chitosan and chitosan/MBA composite nano-coatings increased corrosion resistance, according to the findings. Cytotoxicity tests via fibroblast cells showed that the addition of MBA nanoparticles in a chitosan nanofibrous coating leads to desirable cell attachment and proliferation. Similarly, Singh et al. [110] demonstrated that a nanocomposite coating of hydroxyapatite-bioglass (BG)-iron oxide-chit osan (CS) can successfully enhance surface properties as well as increase the in vitro corrosion resistance and hemocompatibility of a Mg alloy. In this regard, Figure 10A (polarization curves) and Figure 10B (optical macrographs) show the corroded samples after the electrochemical test [110]. The $\mathrm{HA}-\mathrm{BG}-\mathrm{Fe}_{3} \mathrm{O}_{4}$ coating has the minimum $i_{\text {corr }}$ value, and lower defects and smaller pits were observed on the surface in Figure 10B [110]. Since chitosan diminished the infiltration of ions and works as a binder for deposited film, hence, it enhances the corrosion resistance of the substrate $[110,111]$. Similarly, Heise et al. [112] coated magnesium alloy with $\mathrm{CS} / \mathrm{BG} / \mathrm{SiO}_{2}$ and found that adding $\mathrm{SiO}_{2}$ (silica) particles to the coating increased the coating's bioactivity, hardness, and scratch resistance. Alaei et al. [95] also revealed that CS-BG nanocomposite coatings had great adhesion to the $\mathrm{Mg}$ substrate and the ability to form apatite after 7 days in SBF. Zhu et al. [113] showed that $\mathrm{PLLA} /$ magnesium sulfate heptahydrate $\left(\mathrm{MgSO}_{4} \cdot 7 \mathrm{H}_{2} \mathrm{O}\right)$ composite-coated samples could enhance cell adhesion and proliferation and act as a productive barrier on the surface of pure $\mathrm{Mg}$ substrate. Jin et al. [111] prepared a composite coating consisting of FHA and PLA that was fabricated on MAO-Mg alloy. PLA-coated and untreated Mg alloy samples have higher $i_{\text {corr }}$ than composite samples based on electrochemical experiments. It is believed that when the PLA coating is broken, it causes the Mg substrate to come into contact with the corrosion medium and corrode. This means that the direct PLA coating can only control the degradation in a short-term period and is difficult to maintain over the long term.

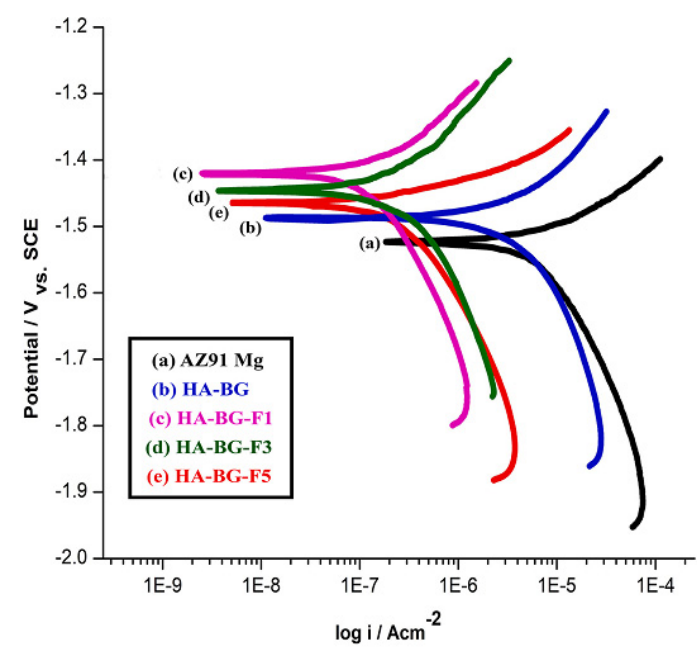

(A)

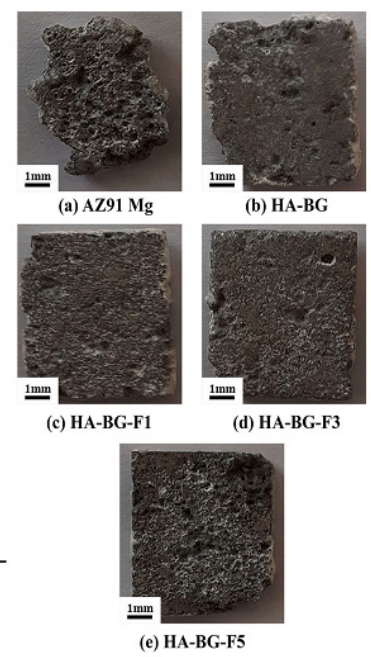

(B)

Figure 10. (A) Potentiodynamic polarization curves and (B) Optical images after the corrosion test for uncoated and $\mathrm{HA}-\mathrm{BG}-\mathrm{Fe}_{3} \mathrm{O}_{4}$ coating. Reprinted with permission from [110]; Copyright 2021 Elsevier.

\section{Polymer-Drug Coatings}

Biodegradable polymers are used as the basic materials in bio-implants, antibacterial performance, drug release, and tissue engineering components. Controlling drug release and surface corrosion were two of the key functions of the composite coating [114]. Bakhsheshi-Rad et al. [115] used an electrospinning method to create gelatin-ciprofloxacin (Gel-Cip) nanofibers on the surface of a $\mathrm{Mg}-1 \mathrm{Ca}$ alloy containing different amounts of 
Cip (0, 2, 4, and $8 \mathrm{wt} \%)$. Microscopical analysis revealed a porous network structure with fiber diameters ranging from 150 to $170 \mathrm{~nm}$. The Gel-Cip nanofibers coating resulted in prolonged drug release, with a rapid drug release of about $20-22 \%$ for the first $12 \mathrm{~h}$, which was followed by a slow release stage until $192 \mathrm{~h}$ that effectively controls the infection. Cip was studied in PBS solution for $240 \mathrm{~h}$ after being released in vitro from Gel nanofibers coating on Mg alloy. Cip was released quickly due to the hydrophilic Gel nanofibers' rapid penetration, whereas Cip was released slowly as a result of the erosion and hydrolysis of the Gel nanofibers. The bare alloy's $E_{\text {corr }}(-1715 \mathrm{mV})$ shifts toward the positive potentials $(-1570 \mathrm{mV})$. In comparison to the untreated alloy $\left(202.55 \mu \mathrm{A} \cdot \mathrm{cm}^{-2}\right)$, the $i_{\text {corr }}$ of Gel-2Cip nanofibers coating $\left(41.55 \mu \mathrm{A} \cdot \mathrm{cm}^{-2}\right)$ is lower, implying that the nanofiber-coated alloy has better corrosion performance. The creation of a protective coating (Gel-Cip nanofibers) on the untreated surface decreased SBF infiltration to the substrate, disrupting the direct interface with the $\mathrm{Mg}$ alloy [18]. On the other hand, $E_{\text {corr }}$ and $i_{\text {corr }}$ were identical in GelCip nanofibers encapsulated with varying amounts of Cip, implying a less significant improvement in degradation rate by enhancement in the concentration of Cip from $2 \%$ to $8 \%$.

The addition of 2 to $4 \%$ Cip to the Gel nanofibers coating considerably improved the antibacterial activity and resistance to corrosion of the bare $\mathrm{Mg}-\mathrm{Ca}$ alloy while having no effect on cytocompatibility [115]. In other study, Bakhsheshi-Rad et al. [116] fabricated $\mathrm{Mg}-\mathrm{Ca}-\mathrm{TiO}_{2}$ (MCT) composite scaffolds containing various contents of doxycycline (DC) with a porous network structure and a high compressive ultimate strength $(5 \pm 0.1 \mathrm{MPa})$ using the space holder process. MCT-DC scaffolds have a porosity of $65-67 \%$ and pore size of $600-800 \mu \mathrm{m}$, according to the findings. The bioactivity results revealed the creation of apatite on the MCT-DC scaffold surface, suggesting that DC had no impediment on MCT bioactivity. The drug release profiles of MCT-DC scaffolds display an initial burst and after that sustained drug release (55-75\%) with the release rate adjustable by changing the DC content [116]. The MCT loaded with $1 \%$ and $5 \%$ DC showed no cytotoxic activity against MG63 cells, but increased DC loading caused some toxicity. Furthermore, all samples had identical release profiles, with minor variations in the amount of DC released. The MCT1DC and MCT-10DC scaffolds had the least $(34.3 \pm 0.6 \%)$ and maximum $(37.2 \pm 0.3 \%)$ burst release in a period of $3 \mathrm{~h}$, respectively, which was followed by a continuous release for the next $15 \mathrm{~h}$. The presence of more DC contents is attributed to the initial increase in drug release in the MCT-10DC scaffold. DC release from all scaffolds, on the other hand, lasted just $20 \mathrm{~h}$. Furthermore, the degradation experiment of scaffolds in $\mathrm{HCl}$ solution revealed no evidence of DC, indicating that the scaffolds released the entire drug within $20 \mathrm{~h}$, which is ideal for treating bone infections [116].

\section{Conclusions and Future Works}

Due to their biodegradability, biocompatibility, and appropriate mechanical properties, magnesium-based biomaterials have a lot of potential in orthopedic applications. However, they have the drawbacks of low corrosion resistance and poor biocompatibility. Polymeric coatings are one of the most popular solutions for these issues. This review article has shown that coating magnesium and its alloys with natural and synthetic polymers can result in functional characteristics such as resistance to corrosion, bioactivity, cytocompatibility, drug release, and bone generation. However, the adhesion strength between the coating and the substrate is not as strong as expected. The issue of peeling off under stress (hydrogen evolution) and corrosion must be addressed. As a result, the future focus may be on enhancing the barrier effect and binding force for a full-life corrosion-resistant service. In this regard, composite coating may be a viable option for increasing the adhesion force of organic biopolymer coating [117-134]. Furthermore, the formation of composite coatings not only improves corrosion resistance but also endows the $\mathrm{Mg}$ alloys with potential bioactivity and biocompatibility in long-term tests. It is important to note that the previous researchers concentrated on only one or two properties, leaving out a wider variety of functionalities. While polymer coatings have enhanced the performance of $\mathrm{Mg}$ alloys in 
the literature, no coating system is yet ready for biomedical applications. Some important coating factors, such as adhesion, permeability, and degradation, must be considered for effective use in implants. As a result, novel strategies for utilizing multipurpose coatings for the development of more effective biodegradable orthopedic Mg-based bioimplants with appropriate bonding strength, high corrosion resistance, and good biocompatibility must be developed. A variety of polymer coatings have been developed in this regard, but the difference in protective properties among those coatings on $\mathrm{Mg}$ alloys is not well understood. As a result, future research should include systematic and long-term comparisons and assessments to clearly identify the benefits and drawbacks of each coating.

Author Contributions: Conceptualization, supervision, formal analysis, writing-review and editing, H.R.B.-R.; writing-original draft preparation, formal analysis, A.S. and S.A.; conceptualization, writing-review and editing, A.F.I., S.S., S.R. and F.B.; conceptualization, writing-review and editing, funding acquisition, M.D. All authors have read and agreed to the published version of the manuscript.

Funding: This research received no external funding.

Institutional Review Board Statement: Not applicable.

Informed Consent Statement: Not applicable.

Data Availability Statement: All data provided in the present manuscript are available to whom it.

Conflicts of Interest: The authors declare that they have no competing/financial conflict of interests.

\section{References}

1. Sezer, N.; Evis, Z.; Kayhan, S.M.; Tahmasebifar, A.; Koç, M. Review of magnesium-based biomaterials and their applications. J. Magnes. Alloys 2018, 6, 23-43. [CrossRef]

2. Razzaghi, M.; Kasiri-Asgarani, M.; Bakhsheshi-Rad, H.R.; Ghayour, H. Microstructure, mechanical properties, and in-vitro biocompatibility of nano-NiTi reinforced $\mathrm{Mg}-3 \mathrm{Zn}-0.5 \mathrm{Ag}$ alloy: Prepared by mechanical alloying for implant applications. Compos. B Eng. 2020, 190, 107947. [CrossRef]

3. Gogheri, M.S.; Kasiri-Asgarani, M.; Bakhsheshi-Rad, H.R.; Ghayour, H.; Rafiei, M. In vitro corrosion behavior and cytotoxicity of polycaprolactone-akermanite-coated friction-welded commercially pure Ti/AZ31 for orthopedic applications. J. Mater. Eng. Perform. 2020, 29, 6053-6065. [CrossRef]

4. Kabir, H.; Munir, K.; Wen, C.; Li, Y. Recent research and progress of biodegradable zinc alloys and composites for biomedical applications: Biomechanical and biocorrosion perspectives. Bioact. Mater. 2021, 6, 836-879. [CrossRef]

5. Fattah-Alhosseini, A.; Babaei, K.; Molaei, M. Plasma electrolytic oxidation (PEO) treatment of zinc and its alloys: A review. Surf. Interfaces 2020, 18, 100441. [CrossRef]

6. Mei, D.; Lamaka, S.V.; Lu, X.; Zheludkevich, M.L. Selecting medium for corrosion testing of bioabsorbable magnesium and other metals-a critical review. Corros. Sci. 2020, 1, 108722. [CrossRef]

7. Yee, D.T.; Koon, J.N.; Huang, Y.; Hou, P.W.; Leo, H.L.; Venkatraman, S.S.; Ang, H.Y. Bioresorbable metals in cardiovascular stents: Material insights and progress. Materialia 2020, 22, 100727.

8. Sezer, N.; Evis, Z.; Koç, M. Additive manufacturing of biodegradable magnesium implants and scaffolds: Review of the recent advances and research trends. J. Magnes. Alloys 2021, 9, 392-415. [CrossRef]

9. Agarwal, S.; Curtin, J.; Duffy, B.; Jaiswal, S. Biodegradable magnesium alloys for orthopaedic applications: A review on corrosion, biocompatibility and surface modifications. Mater. Sci. Eng. C 2016, 68, 948-963. [CrossRef]

10. Yang, J.; Koons, G.L.; Cheng, G.; Zhao, L.; Mikos, A.G.; Cui, F. A review on the exploitation of biodegradable magnesium-based composites for medical applications. Biomed. Mater. 2018, 13, 022001. [CrossRef]

11. Li, H.; Yang, H.; Zheng, Y.; Zhou, F.; Qiu, K.; Wang, X. Design and characterizations of novel biodegradable ternary Zn-based alloys with IIA nutrient alloying elements Mg, Ca and Sr. Mater. Des. 2015, 83, 95-102. [CrossRef]

12. Ali, M.; Hussein, M.A.; Al-Aqeeli, N. Magnesium-based composites and alloys for medical applications: A review of mechanical and corrosion properties. J. Magnes. Alloys 2019, 792, 1162-1190. [CrossRef]

13. Zhang, H.Y.; Jiang, H.B.; Kim, J.E.; Zhang, J.E.; Kim, K.M.; Kwon, J.S. Bioresorbable magnesium-reinforced PLA membrane for guided bone/ tissue regeneration. J. Mech. Behav. Biomed. Mater. 2020, 112, 104061. [CrossRef]

14. Adel-Gawad, S.; Shoeib, M.A. Corrosion studies and microstructure of $\mathrm{Mg}-\mathrm{Zn}-\mathrm{Ca}$ alloys for biomedical applications. Surf. Interfaces 2019, 14, 108-116. [CrossRef]

15. Daroonparvar, M.; Khan, M.F.; Saadeh, Y.; Kay, C.M.; Gupta, R.K.; Kasar, A.K.; Kumar, P.; Misra, M.; Menezes, P.L.; BakhsheshiRad, H.R. Enhanced corrosion resistance and surface bioactivity of AZ31B Mg alloy by high pressure cold sprayed monolayer Ti and bilayer Ta/Ti coatings in simulated body fluid. Mater. Chem. Phys. 2020, 256, 123627. [CrossRef] 
16. Daroonparvar, M.; Yajid, M.A.; Gupta, R.K.; Yusof, N.M.; Bakhsheshi-Rad, H.R.; Ghandvar, H.; Ghasemi, E. Antibacterial activities and corrosion behavior of novel PEO/nanostructured $\mathrm{ZrO}_{2}$ coating on $\mathrm{Mg}$ alloy. Trans. Nonferr. Met. Soc. China 2018, 28, 1571-1581. [CrossRef]

17. Daroonparvar, M.; Khan, M.F.; Saadeh, Y.; Kay, C.M.; Kasar, A.K.; Kumar, P.; Esteves, L.; Misra, M.; Menezes, P.; Kalvala, P.R.; et al. Modification of surface hardness, wear resistance and corrosion resistance of cold spray Al coated AZ31B Mg alloy using cold spray double layered $\mathrm{Ta} / \mathrm{Ti}$ coating in $3.5 \mathrm{wt} \% \mathrm{NaCl}$ solution. Corros. Sci. 2020, 176, 109029. [CrossRef]

18. Li, L.Y.; Cui, L.Y.; Zeng, R.C.; Li, S.Q.; Chen, X.B.; Zheng, Y.; Kannan, M.B. Advances in functionalized polymer coatings on biodegradable magnesium alloys-A review. Acta Biomater. 2018, 79, 23-36. [CrossRef] [PubMed]

19. Saberi, A.; Bakhsheshi-Rad, H.R.; Karamian, E.; Kasiri-Asgarani, M.; Ghomi, H. A study on the corrosion behavior and biological properties of polycaprolactone/bredigite composite coating on biodegradable Mg-Zn-Ca-GNP nanocomposite. Prog. Org. Coat. 2020, 147, 105822. [CrossRef]

20. Kirkland, N.T.; Birbilis, N.; Staiger, M.P. Assessing the corrosion of biodegradable magnesium implants: A critical review of current methodologies and their limitations. Acta Biomater. 2012, 8, 925-936. [CrossRef]

21. Farshid, S.; Kharaziha, M. Micro and nano-enabled approaches to improve the performance of plasma electrolytic oxidation coated magnesium alloys. J. Magnes. Alloys 2020. [CrossRef]

22. Lin, Z.; Wang, T.; Yu, X.; Sun, X.; Yang, H. Functionalization treatment of micro-arc oxidation coatings on magnesium alloys: A review. J. Alloys Compds. 2021, 21, 160453. [CrossRef]

23. Zhang, D.; Peng, F.; Liu, X. Protection of magnesium alloys: From physical barrier coating to smart self-healing coating. J. Alloys Compd. 2020, 4, 157010.

24. Li, X.; Liu, X.; Wu, S.; Yeung, K.W.; Zheng, Y.; Chu, P.K. Design of magnesium alloys with controllable degradation for biomedical implants: From bulk to surface. Acta Biomater. 2016, 45, 2-30. [CrossRef]

25. Singh, N.; Batra, U.; Kumar, K.; Mahapatro, A. Investigating $\mathrm{TiO}_{2}-\mathrm{HA}-\mathrm{PCL}$ hybrid coating as an efficient corrosion resistant barrier of ZM21 Mg alloy. J. Magnes. Alloys 2021, 9, 627-646. [CrossRef]

26. Zhou, H.; Liang, B.; Jiang, H.; Deng, Z.; Yu, K. Magnesium-based biomaterials as emerging agents for bone repair and regeneration: From mechanism to application. J. Magnes. Alloys 2021. [CrossRef]

27. Prajapati, S.K.; Jain, A.; Jain, A.; Jain, S. Biodegradable polymers and constructs: A novel approach in drug delivery. Eur. Polym. J. 2019, 120, 109191. [CrossRef]

28. Chang, B.; Ahuja, N.; Ma, C.; Liu, X. Injectable scaffolds: Preparation and application in dental and craniofacial regeneration. Mater. Sci. Eng. R 2017, 111, 1-26. [CrossRef]

29. Liu, G.Y.; Hu, J.; Ding, Z.K.; Wang, C. Bioactive calcium phosphate coating formed on micro-arc oxidized magnesium by chemical deposition. Appl. Surf. Sci. 2011, 257, 2051-2057. [CrossRef]

30. Radha, R.; Sreekanth, D. Insight of magnesium alloys and composites for orthopedic implant applications-A review. J. Magnes. Alloys 2017, 5, 286-312. [CrossRef]

31. Raquez, J.M.; Habibi, Y.; Murariu, M.; Dubois, P. Polylactide (PLA)-based nanocomposites. Prog. Polym. Sci. 2013, 38, 1504-1542. [CrossRef]

32. Alabbasi, A.; Liyanaarachchi, S.; Kannan, M.B. Polylactic acid coating on a biodegradable magnesium alloy: An in vitro degradation study by electrochemical impedance spectroscopy. Thin Solid Film. 2012, 520, 6841-6844. [CrossRef]

33. Sheng, Y.; Tian, L.; Wu, C.; Qin, L.; Ngai, T. Biodegradable poly (L-lactic acid)(PLLA) coatings fabricated from nonsolvent induced phase separation for improving corrosion resistance of magnesium rods in biological fluids. Langmuir 2018, 34, 10684-10693. [CrossRef]

34. Zhang, J.; Pei, J.; Wang, H.; Shi, Y.; Niu, J.; Yuan, F.; Huang, H.; Zhang, H.; Yuan, G. A facile preparation of poly (lactic acid)/brushite bilayer coating on biodegradable magnesium alloys with multiple functionalities for orthopedic application. ACS Appl. Matter. Interfaces 2017, 9, 9437-9448. [CrossRef]

35. Li, B.; Zhang, K.; Yang, W.; Yin, X.; Liu, Y. Enhanced corrosion resistance of $\mathrm{HA} / \mathrm{CaTiO}_{3} / \mathrm{TiO}_{2} / \mathrm{PLA}$ coated AZ31 alloy. J. Taiwan Inst. Chem. Eng. 2016, 59, 465-473. [CrossRef]

36. Shi, P.; Niu, B.; Shanshan, E.; Chen, Y.; Li, Q. Preparation and characterization of PLA coating and PLA/MAO composite coatings on AZ31 magnesium alloy for improvement of corrosion resistance. Surf. Coat. Technol. 2015, 262, 26-32. [CrossRef]

37. Malayoglu, U.; Tekin, K.C.; Shrestha, S. Influence of post-treatment on the corrosion resistance of PEO coated AM50B and AM60B Mg alloys. Surf. Coat. Technol. 2010, 205, 1793-1798. [CrossRef]

38. Bakhsheshi-Rad, H.R.; Hamzah, E.; Ebrahimi-Kahrizsangi, R.; Daroonparvar, M.; Medraj, M. Fabrication and characterization of hydrophobic microarc oxidation/poly-lactic acid duplex coating on biodegradable Mg-Ca alloy for corrosion protection. Vacuum 2016, 125, 185-188. [CrossRef]

39. Wei, Z.L.; Tian, P.; Liu, X.Y.; Zhou, B.X. In vitro degradation, hemolysis, and cytocompatibility of PEO/PLLA composite coating on biodegradable AZ31 alloy. J. Biomed. Mater. Res. Part B 2015, 103, 342-354. [CrossRef] [PubMed]

40. Zeng, R.C.; Cui, L.Y.; Jiang, K.; Liu, R.; Zhao, B.D.; Zheng, Y.F. In vitro corrosion and cytocompatibility of a microarc oxidation coating and poly (l-lactic acid) composite coating on Mg-1Li-1Ca alloy for orthopedic implants. ACS Appl. Mater. Interfaces 2016, 8, 10014-10028. [CrossRef]

41. Yin, Z.Z.; Qi, W.C.; Zeng, R.C.; Chen, X.B.; Gu, C.D.; Guan, S.K.; Zheng, Y.F. Advances in coatings on biodegradable magnesium alloys. J. Magnes. Alloys 2020, 8, 42-65. [CrossRef] 
42. Li, J.N.; Cao, P.; Zhang, X.N.; Zhang, S.X.; He, Y.H. In vitro degradation and cell attachment of a PLGA coated biodegradable Mg-6Zn based alloy. J. Mater. Sci. 2010, 45, 6038-6045. [CrossRef]

43. Chen, L.; Sheng, Y.; Zhou, H.; Li, Z.; Wang, X.; Li, W. Influence of a MAO+PLGA coating on biocorrosion and stress corrosion cracking behavior of a magnesium alloy in a physiological environment. Corros. Sci. 2019, 148, 134-143. [CrossRef]

44. Razzaghi, M.; Kasiri-Asgarani, M.; Bakhsheshi-Rad, H.R.; Ghayour, H. In Vitro Bioactivity and Corrosion of PLGA/hardystonite Composite Coated Magnesium-Based Nanocomposite for Implant Applications. Int. J. Min. Met. Mater. 2021, 28, 168-178. [CrossRef]

45. Shi, Y.; Pei, J.; Zhang, L.; Lee, B.K.; Yun, Y.; Zhang, J.; Li, Z.; Gu, S.; Park, K.; Yuan, G. Understanding the effect of magnesium degradation on drug release and anti-proliferation on smooth muscle cells for magnesium-based drug eluting stents. Corros. Sci. 2017, 123, 297-309. [CrossRef]

46. Palumboa, G.; Cusannoa, A.; Romeu, M.G.; Bagudanch, I.; Negrini, N.C.; Villa, T.; Farè, S. Point Incremental Forming and Electrospinning to produce biodegradable magnesium (AZ31) biomedical prostheses coated with porous PCL. Mater. Today Proc. 2019, 7, 394-401. [CrossRef]

47. Yazdimamaghani, M.; Razavi, M.; Vashaee, D.; Tayebi, L. Development and degradation behavior of magnesium scaffolds coated with polycaprolactone for bone tissue engineering. Mater. Lett. 2014, 132, 106-110. [CrossRef]

48. Dai, Y.; Lu, Y.; Li, D.; Yu, K.; Jiang, D.; Yan, Y.; Chen, L.; Xiao, T. Effects of polycaprolactone coating on the biodegradable behavior and cytotoxicity of $\mathrm{Mg}-6 \% \mathrm{Zn}-10 \% \mathrm{Ca}_{3}\left(\mathrm{PO}_{4}\right)_{2}$ composite in simulated body fluid. Mater. Lett. 2017, 198, 118-120. [CrossRef]

49. Bakhsheshi-Rad, H.R.; Hamzah, E.; Abdul-Kadir, M.R.; Daroonparvar, M.; Medraj, M. Corrosion and mechanical performance of double-layered nano-Al/PCL coating on Mg-Ca-Bi alloy. Vacuum 2015, 119, 95-98. [CrossRef]

50. Bakhsheshi-Rad, H.R.; Hamzah, E.; Bagheriyan, S.; Daroonparvar, M.; Kasiri-Asgarani, M.; Shah, A.M.; Medraj, M. Preparation and performance of plasma/polymer composite coatings on magnesium alloy. J. Mater. Eng. Perform. 2016, 25, 3948-3959. [CrossRef]

51. Bakhsheshi-Rad, H.R.; Hamzah, E.; Kasiri-Asgarani, M.; Jabbarzare, S.; Iqbal, N.; Kadir, M.A. Deposition of nanostructured fluorine-doped hydroxyapatite-polycaprolactone duplex coating to enhance the mechanical properties and corrosion resistance of Mg alloy for biomedical applications. Mater. Sci. Eng. C 2016, 60, 526-537. [CrossRef]

52. Bakhsheshi-Rad, H.R.; Hamzah, E.; Abdul-Kadir, M.R.; Saud, S.N.; Kasiri-Asgarani, M.; Ebrahimi-Kahrizsangi, R. The Mechanical Properties and Corrosion Behavior of Double-Layered Nano Hydroxyapatite-Polymer Coating on Mg-Ca Alloy. J. Mater. Eng. Perform. 2015, 24, 4010-4021. [CrossRef]

53. Bakhsheshi-Rad, H.R.; Hamzah, E.; Daroonparvar, M.; Kadir, M.A.; Kasiri-Asgarani, M.; Staiger, M.P. Enhancement of corrosion resistance and mechanical properties of Mg-1.2Ca-2Bi via a hybrid silicon-biopolymer coating system. Surf. Coat. Tech. 2016, 301, 133-139. [CrossRef]

54. Yuan, T.T.; Yu, J.; Cao, J.; Gao, F.; Zhu, Y.; Cheng, Y. Fabrication of a delaying biodegradable magnesium alloy-based esophageal stent via coating elastic polymer. Materials 2016, 9, 384-394. [CrossRef] [PubMed]

55. Abdal-hay, A.; Amna, T.; Lim, J.K. Biocorrosion and osteoconductivity of PCL/nHA composite porous film-based coating of magnesium alloy. Solid State Sci. 2013, 18, 131-140. [CrossRef]

56. Roshan, N.R.; Hassannejad, H.; Nouri, A. Corrosion and mechanical behavior of biodegradable PLA-cellulose nanocomposite coating on AZ31 magnesium alloy. Surf. Eng. 2021, 37, 236-245. [CrossRef]

57. Bakhsheshi-Rad, H.R.; Ismail, A.F.; Aziz, M.; Akbari, M.; Hadisi, Z.; Khoshnava, S.M.; Pagan, E.; Chen, X. Co-incorporation of graphene oxide/silver nanoparticle into poly- L-lactic acid fibrous: A route toward the development of cytocompatible and antibacterial coating layer on magnesium implants. Mater. Sci. Eng. C 2020, 111, 110812. [CrossRef]

58. Bakhsheshi-Rad, H.R.; Akbaric, M.; Ismai, A.F.; Aziz, M.; Hadisi, Z.; Pagan, E.; Daroonparvar, M.R.; Chena, X. Coating biodegradable magnesium alloys with electrospun poly-L- lactic acid-akermanite-doxycycline nanofibers for enhanced biocompatibility, antibacterial activity, and corrosion resistance. Surf. Coat. Tech. 2019, 377, 124898. [CrossRef]

59. Lin, L.H.; Lee, H.P.; Yeh, M.L. Characterization of a Sandwich PLGA-Gallic Acid-PLGA Coating on Mg Alloy ZK60 for Bioresorbable Coronary Artery Stents. Materials 2020, 13, 5538. [CrossRef]

60. Liu, L.; Huang, B.; Liu, X.; Yuan, W.; Zheng, Y.; Li, Z.; Yeung, K.W.; Zhu, S.; Liang, Y.; Cui, Z.; et al. Photo-controlled degradation of PLGA/Ti3C2 hybrid coating on Mg-Sr alloy using near infrared light. Bioact. Mater. 2021, 6, 568-578. [CrossRef] [PubMed]

61. Chen, Y.; Song, Y.; Zhang, S.; Li, J.; Zhao, C.; Zhang, X. Interaction between a high purity magnesium surface and PCL and PLA coatings during dynamic degradation. Biomed. Mater. 2011, 6, 025005. [CrossRef]

62. Park, M.; Lee, J.E.; Park, C.G.; Lee, S.H.; Seok, H.K.; Choy, Y.B. Polycaprolactone coating with varying thicknesses for controlled corrosion of magnesium. J. Coat. Technol. Res. 2013, 10, 695-706. [CrossRef]

63. Iqbal, N.; Iqbal, S.; Iqbal, T.; Bakhsheshi-Rad, H.R.; Alsakkaf, A.; Kamil, A.; Kadir, M.R.A.; Idris, M.H.; Raghav, H.B. Zinc-doped hydroxyapatite-zeolite/polycaprolactone composites coating on magnesium substrate for enhancing in-vitro corrosion and antibacterial performance. Trans. Nonferrous Met. Soc. China 2020, 30, 123-133. [CrossRef]

64. Bakhsheshi-Rad, H.R.; Hamzah, E.; Shuang, C.P.; Berto, F. Preparation of poly ( $\varepsilon$-caprolactone)-hydroxyapatite composite coating for improvement of corrosion performance of biodegradable magnesium. Mater. Des. Proc. Comm. 2020, 2, e170. [CrossRef]

65. Tian, P.; Xu, D.; Liu, X. Mussel-inspired functionalization of PEO/PCL composite coating on abiodegradable AZ31 magnesium alloy. Colloids Surf. B: Biointerfaces 2016, 141, 327-337. [CrossRef] 
66. Makkar, P.; Kang, H.J.; Padalhin, A.R.; Park, I.; Moon, B.G.; Lee, B.T. Development and properties of duplex $\mathrm{MgF}_{2} / \mathrm{PCL}$ coatings on biodegradable magnesium alloy for biomedical applications. J. Mater. Sci. Mater. Med. 2018, 13, e0193927. [CrossRef] [PubMed]

67. Bakhsheshi-Rad, H.R.; Hamzah, E.; Ismail, A.F.; Sharer, Z.; Abdul-Kadir, M.R.; Daroonparvar, M.; Saud, S.N.; Medraj, M. Synthesis and corrosion behavior of a hybrid bioceramic-biopolymer coating on biodegradable $\mathrm{Mg}$ alloy for orthopaedic implants. J. Alloys Compd. 2015, 648, 1067-1071. [CrossRef]

68. Hahn, B.D.; Park, S.D.; Choi, J.J.; Ryu, J.; Yoon, W.H.; Choi, J.H.; Kim, H.E.; Kim, S.G. Aerosol deposition of hydroxyapatitechitosan composite coatings on biodegradable magnesium alloy. Surf. Coat. Tech. 2011, 205, 3112-3118. [CrossRef]

69. Liangjian, C.; Jun, Z.; Kun, Y.; Chang, C.; Yilong, D.; Xueyan, Q.; Zhiming, Y. Improving of in vitro Biodegradation Resistance in a Chitosan Coated Magnesium Bio-composite. Rare Metal Mat. Eng. 2015, 44, 1862-1865. [CrossRef]

70. Heise, S.; Höhlinger, M.; Hernández, Y.T.; Palacio, J.J.P.; Ortiz, J.A.R.; Wagener, V.; Virtanen, S.; Boccaccini, A.R. Electrophoretic deposition and characterization of chitosan/bioactive glass composite coatings on $\mathrm{Mg}$ alloy substrates. Electrochim. Acta 2017, 232, 456-464. [CrossRef]

71. Höhlinger, M.; Christa, D.; Zimmermann, V.; Heise, S.; Boccaccini, A.R.; Virtanen, S. Influence of proteins on the corrosion behavior of a chitosan-bioactive glass coated magnesium alloy. Mater. Sci. Eng. C 2019, 100, 706-714. [CrossRef] [PubMed]

72. Yadav, V.S.; Sankar, M.R.; Pandey, L.M. Coating of bioactive glass on magnesium alloys to improve its degradation behavior: Interfacial aspects. J. Magnes. Alloys 2020, 8, 999-1015. [CrossRef]

73. Bakhsheshi-Rad, H.R.; Chen, X.; Ismail, A.F.; Aziz, M.; Abdolahi, E.; Mahmoodiyan, F. Improved antibacterial properties of an $\mathrm{Mg}-\mathrm{Zn}-\mathrm{Ca}$ alloy coated with chitosan nanofibers incorporating silver sulfadiazine multiwall carbon nanotubes for bone implants. Polym. Adv. Tech. 2019, 30, 1333-1339. [CrossRef]

74. Jia, Z.J.; Xiong, P.; Shi, Y.Y.; Zhou, W.H.; Cheng, Y.; Zheng, Y.F.; Xi, T.F.; Wei, S.C. Inhibitor encapsulated, self-healable and cytocompatible chitosan multilayer coating on biodegradable $\mathrm{Mg}$ alloy: A pH-responsive design. J. Mater. Chem. B 2016, 4, 2498-2511. [CrossRef]

75. Caladoa, L.M.; Tarybaa, M.G.; Carmezima, M.J.; Montemora, M.F. Self-healing ceria-modified coating for corrosion protection of AZ31 magnesium alloy. Corros. Sci. 2018, 142, 12-21. [CrossRef]

76. Bahatibieke, A.; Qin, H.; Cui, T.; Liu, Y.; Wang, Z. In vivo and in simulated body fluid degradation behavior and biocompatibility evaluation of anodic oxidation-silane-chitosan-coated Mg-4.0 Zn-0.8 Sr alloy for bone application. Mater. Sci. Eng. C 2021, 120, 111771. [CrossRef]

77. Bakhsheshi-Rad, H.R.; Hamzah, E.; Ying, W.S.; Razzaghi, M.; Sharif, S.; Ismail, A.F.; Berto, F. Improved Bacteriostatic and Anticorrosion Effects of Polycaprolactone/Chitosan Coated Magnesium via Incorporation of Zinc Oxide. Materials 2021, 14, 1930. [CrossRef]

78. Bao, Q.; Zhao, L.; Jing, H.; Xu, Q. Microstructure of Hydroxyapatite/Collagen Coating on AZ31 Magnesium Alloy by a Solution Treatment. J. Biomimetics. Biomater. Biomed. Eng. 2017, 30, 30-38. [CrossRef]

79. Park, C.H.; Pant, H.R.; Kim, C.S. Effect on corrosion behavior of collagen film/fiber coated AZ31 magnesium alloy. Dig. J. Nanomater. Bios. 2013, 8, 1227-1234.

80. Córdoba, L.C.; Marques, A.; Taryba, M.; Coradin, T.; Montemor, F. Hybrid coatings with collagen and chitosan for improved bioactivity of Mg alloys. Surf. Coat. Tech. 2018, 341, 103-113. [CrossRef]

81. Guo, Y.; Sub, Y.; Guc, R.; Zhangd, Z.; Lia, G.; Liana, J.; Rend, L. Enhanced corrosion resistance and biocompatibility of biodegradable magnesium alloy modified by calcium phosphate/collagen coating. Surf. Coat. Tech. 2020, 401, 126318. [CrossRef]

82. Barbeck, M.; Kuhnel, L.; Witte, F.; Pissarek, J.; Precht, C.; Xiong, X.; Krastev, R.; Wegner, N.; Walther, F.; Jung, O. Degradation, bone regeneration and tissue response of an innovative volume stable magnesium- supported GBR/GTR barrier membrace. Int. J. Mol. Sci. 2020, 21, 3098. [CrossRef]

83. Yang, Y.; Xiong, X.; Chen, J.; Peng, X.; Chen, D.; Pan, F. Latest Research advances in magnesium and magnesium alloys worldwide. J. Magnes. Alloys 2020, 8, 1-41.

84. Guo, Y.; Jia, S.; Qiao, L.; Su, Y.; Gu, R.; Li, G.; Lian, J. Enhanced corrosion resistance and biocompatibility of polydopamine/dicalcium phosphate dihydrate/collagen composite coating on magnesium alloy for orthopedic applications. J. Alloys Compd. 2020, 817, 152782. [CrossRef]

85. Jothi, V.; Adesina, A.Y.; Kumar, A.M.; Rahman, M.M.; Nirmal Ram, J.S. Enhancing the biodegradability and surface protective performance of AZ31 Mg alloy using polypyrrole/gelatin composite coatings with anodized Mg surface. Surf. Coat. Tech. 2020, 380, 125139. [CrossRef]

86. Jafarzadeh, A.; Ahmadi, T.; Dehaghanic, M.T.; Mohemia, K. Synthesis, Corrosion and Bioactivity Evaluation of Gelatin/Silicon and Magnesium Co-Doped Fluorapatite Nanocomposite Coating Applied on AZ31 Mg Alloy. Russ. J. Non-Ferr. Met. 2018, 59, 458-464. [CrossRef]

87. Akram, M.; Arshad, N.; Aktan, M.K.; Braem, A. Alternating Current Electrophoretic Deposition of Chitosan-Gelatin-Bioactive Glass on Mg-Si-Sr Alloy for Corrosion Protection. ACS Appl. Bio Mater. 2020, 3, 7052-7060. [CrossRef]

88. Qi, H.; Heise, S.; Zhou, J.; Schuhladen, K.; Yang, Y.; Cui, N.; Dong, R.; Virtanen, S.; Chen, Q.; Boccaccini, A.R.; et al. Electrophoretic deposition of bioadaptive drug delivery coatings on magnesium alloy for bone repair. ACS Appl. Mater. Interfaces 2019, 11, 8625-8634. [CrossRef] [PubMed]

89. Wang, C.; Fanga, H.; Hang, C.; Sun, Y.; Peng, Z.; Weid, W.; Wang, Y. Fabrication and characterization of silk fibroin coating on APTES pretreated Mg-Zn-Ca alloy. Mater. Sci. Eng. C 2020, 110, 531-538. [CrossRef] [PubMed] 
90. Xu, W.; Yagoshi, K.; Asakura, T.; Sasaki, M.; Niidome, T. Silk Fibroin as a Coating Polymer for Sirolimus-Eluting Magnesium Alloy Stents. ACS Appl. Bio Mater. 2020, 3, 531-538. [CrossRef]

91. Fang, H.; Wang, C.; Zhou, S.; Li, G.; Tian, Y.; Suga, T. Exploration of the enhanced performances for silk fibroin/sodium alginate composite coatings on biodegradable $\mathrm{Mg}-\mathrm{Zn}-\mathrm{Ca}$ alloy. J. Magnes. Alloys 2020. [CrossRef]

92. Wang, C.; Fang, H.; Qi, X.; Hang, C.; Sun, Y.; Peng, Z.; Wei, W.; Wang, Y. Silk fibroin film-coated MgZnCa alloy with enhanced in vitro and in vivo performance prepared using surface activation. Acta Biomater. 2019, 91, 99-111. [CrossRef] [PubMed]

93. Xiong, P.; Jia, Z.; Li, M.; Zhou, W.; Yan, J.; Wu, Y.; Cheng, Y.; Zheng, Y. Biomimetic Ca, Sr/P-doped silk fibroin films on Mg-1Ca alloy with dramatic corrosion resistance and osteogenic activities. ACS Biomater. Sci. Eng. 2018, 4, 3163-3176. [CrossRef]

94. Bai, K.; Zhang, Y.; Fu, Z.; Cui, C.; Meng, E.; Guan, S.; Hu, J. Fabrication of chitosan /magnesium phosphate composite coating and the in vitro degradation properties of coated magnesium alloy. Mater. Lett. 2012, 73, 59-61. [CrossRef]

95. Alaei, M.; Atapour, M.; Labbaf, S. Electrophoretic deposition of chitosan-bioactive glass nanocomposite coatings on AZ91 Mg alloy for biomedical applications. Prog. Org. Coat. 2020, 147, 105803. [CrossRef]

96. Soleymani, F.; Emadi, R.; Sadeghzade, S.; Tavangarian, F. Applying Baghdadite/ PCL/ Chitosan Nanocomposite Coating on AZ91 Magnesium Alloy to Improve Corrosion Behavior Bioactivity and Biodegradability. Coatings 2019, 9, 789. [CrossRef]

97. Zhao, J.; Chen, L.J.; Yu, K.; Chen, C.; Dai, Y.L.; Qiao, X.Y.; Yan, Y.; Yu, Z.M. Effects of chitosan coating on biocompatibility of $\mathrm{Mg}-6 \% \mathrm{Zn}-10 \% \mathrm{Ca}_{3}\left(\mathrm{PO}_{4}\right)_{2}$ implant. Trans. Nonferrous Met. Soc. China 2015, 25, 824-831. [CrossRef]

98. Gao, F.; Hub, Y.; Gong, Z.; Liua, T.; Gong, T.; Liua, S.; Zhang, C.; Quan, L.; Kaveendran, B.; Pan, C. Fabrication of chitosan/heparinized graphene oxide multilayer coating to improve corrosion resistance and biocompatibility of magnesium alloys. Mater. Sci. Eng. C 2019, 104, 109947. [CrossRef] [PubMed]

99. Córdoba, L.C.; Hélary, C.; Montemor, F.; Coradin, T. Bi-layered silane- $\mathrm{TiO}_{2} /$ collagen coating to control biodegradation and biointegration of Mg alloys. Mater. Sci. Eng. C 2019, 94, 126-138. [CrossRef]

100. Song, J.; Cui, X.; Jin, G.; Cai, Z.; Liu, E.; Li, X.; Chen, Y.; Lu, B. Self-healing conversion coating with gelatin-chitosan microcapsules containing inhibitor on AZ91D alloy. Surf. Eng. 2018, 34, 79-84. [CrossRef]

101. Chen, Y.; Wang, J.; Dou, J.; Yu, H.; Chen, C. Layer by layer assembled chitosan $\left(\mathrm{TiO}_{2}\right)$-heparin composite coatings on MAO-coated Mg alloys. Mater. Lett. 2020, 281, 128640. [CrossRef]

102. Fang, H.; Wang, C.; Zhou, S.; Zheng, Z.; Lu, T.; Li, G.; Tian, Y.; Suga, T. Enhanced adhesion and anticorrosion of silk fibroin coated biodegradable Mg-Zn-Ca alloy via a two-step plasma activation. Corros. Sci. 2020, 168, 108466. [CrossRef]

103. Chang, L.; Li, X.; Tang, X.; Zhang, H.; He, D.; Wang, Y.; Zhao, J.; Li, J.; Wang, J.; Zhu, S.; et al. Micro-patterned hydroxyapatite/silk fibroin coatings on $\mathrm{Mg}-\mathrm{Zn}-\mathrm{Y}-\mathrm{Nd}-\mathrm{Zr}$ alloys for better corrosion resistance and cell behavior guidance. Front. Mater. Sci. 2020, 14, 413-425. [CrossRef]

104. Xiong, P.; Yan, J.L.; Wang, P.; Jia, Z.; Zhou, W.; Yuan, W.; Li, Y.; Liu, Y.; Cheng, Y.; Chen, D.; et al. A pH-Sensitive Self-healing Coating for Biodegradable Magnesium Implants. Acta Biomater. 2019, 98, 160-173. [CrossRef]

105. Gnedenkov, S.V.; Sinebryukhov, S.L.; Mashtalyar, D.V.; Egorkin, V.S.; Sidorova, M.V.; Gnedenkov, A.S. Composite polymercontaining protective coatings on magnesium alloy MA8. Corros. Sci. 2014, 85, 52-59. [CrossRef]

106. Chen, P.; Sun, J.; Zhu, Y.; Yu, X.; Meng, L.; Li, Y.; Liu, X. Corrosion Resistance of Biodegradable Mg with a Composite Polymer Coating. J. Biomater. Sci. Polym. Ed. 2016, 27, 1763-1774. [CrossRef]

107. Chen, Y.Q.; Zhao, S.; Chen, M.Y.; Zhang, W.T.; Mao, J.L.; Zhao, Y.C.; Maitz, M.F.; Huang, N.; Wan, G.L. Sandwiched polydopamine (PDA) layer for titanium dioxide $\left(\mathrm{TiO}_{2}\right)$ coating on magnesium to enhance corrosion protection. Corros. Sci. 2015, 96, 67-73. [CrossRef]

108. Zheng, Q.; Li, J.; Yuan, W.; Liu, X.; Tan, L.; Zheng, Y.; Yeung, K.W.; Wu, S. Metal-Organic Frameworks Incorporated Polycaprolactone Film for Enhanced Corrosion Resistance and Biocompatibility of Mg Alloy. ACS Sustain. Chem. Eng. 2019, 7, 18114-18124. [CrossRef]

109. Rahimi, M.; Aghdam, R.M.; Sohi, M.H.; Rezayan, A.H.; Ettelaei, M. Improving biocompatibility and corrosion resistance of anodized AZ31 Mg alloy by electrospun chitosan/mineralized bone allograft (MBA) nanocoatings. Surf. Coat. Technol. 2021, 405, 126627. [CrossRef]

110. Singh, S.; Singh, G.; Bala, N. Electrophoretic deposition of $\mathrm{Fe}_{3} \mathrm{O}_{4}$ nanoparticles incorporated hydroxyapatite-bioglass-chitosan nanocomposite coating on AZ91 Mg alloy. Mater. Today Commun. 2021, 26, 101870. [CrossRef]

111. Jin, J.; Zhou, S.; Duan, H. Preparation and properties of heat treated FHA@ PLA composition coating on micro-oxidized AZ91D magnesium alloy. Surf. Coat. Tech. 2018, 349, 50-60. [CrossRef]

112. Heise, S.; Wirth, T.; Höhlinger, M.; Hernánde, Y.T.; Ortiz, J.A.; Wagener, V.; Virtanen, S.; Boccaccini, A.R. Electrophoretic deposition of chitosan/bioactive glass/silica coatings on stainless steel and WE43 Mg alloy substrates. Surf. Coat. Tech. 2018, 344, 553-563. [CrossRef]

113. Zhu, Y.; Zheng, L.; Liu, W.; Qin, L.; Ngai, T. Poly (l-lactic acid)(PLLA)/MgSO $4 \cdot 7 \mathrm{H}_{2} \mathrm{O}$ Composite Coating on Magnesium Substrates for Corrosion Protection and Cytocompatibility Promotion. ACS Appl. Bio Mater. 2020, 3, 1364-1373. [CrossRef]

114. Hornberger, H.; Virtanen, S.; Boccaccini, A.R. Biomedical coatings on magnesium alloys-A review. Acta Biomater. 2012, 8, 2442-2455. [CrossRef] [PubMed]

115. Bakhsheshi-Rad, H.R.; Hadisi, Z.; Hamzah, E.; Ismail, A.F.; Aziz, M.; Kashefian, M. Drug delivery and cytocompatibility of ciprofloxacin loaded gelatin nanofibers-coated Mg alloy. Mat. Lett. 2017, 207, 179-182. [CrossRef] 
116. Bakhsheshi-Rad, H.R.; Hamzah, E.; Staiger, M.P.; Dias, G.J.; Hadisi, Z.; Saheban, M.; Kashefian, M. Drug release, cytocompatibility, bioactivity, and antibacterial activity of doxycycline loaded $\mathrm{Mg}-\mathrm{Ca}-\mathrm{TiO}_{2}$ composite scaffold. Mater. Des. 2018, 139, $212-221$. [CrossRef]

117. Kania, A.; Szindler, M.M.; Szindler, M. Structure and corrosion behavior of $\mathrm{TiO}_{2}$ thin films deposited by ALD on a biomedical magnesium alloy. Coatings 2021, 11, 70. [CrossRef]

118. Novotny, J.; Michna, S.; Hren, I.; Cais, J.; Lysonkova, I.; Svorcik, V. PTFE based multilayer micro-coatings for aluminum AlMg3 forms used in tire production. Coatings 2021, 11, 119. [CrossRef]

119. Ashkenazi, D.; Inberg, A.; Shacham-Diamand, Y.; Stern, A. Gold, silver, and electrum electroless plating on additively manufactured laser powder-bed fusion AlSi10Mg parts: A review. Coatings 2021, 11, 422. [CrossRef]

120. Chen, Y.; Yao, W.; Wu, L.; Chen, J.; Pan, F. Effect of microstructure on layered double hydroxides film growth on Mg-2Zn-xMn alloy. Coatings 2021, 11, 59. [CrossRef]

121. Kozelskaya, A.; Dubinenko, G.; Vorobyev, A.; Fedotkin, A.; Korotchenko, N.; Gigilev, A.; Shesterikov, E.; Zhukov, Y.; Tverdokhlebov, S. Porous $\mathrm{CaP}$ coatings formed by combination of plasma electrolytic oxidation and RF-magnetron sputtering. Coatings 2020, 10, 1113. [CrossRef]

122. Hou, S.; Yu, W.; Yang, Z.; Li, Y.; Yang, L.; Lang, S. Properties of titanium oxide coating on MgZn alloy by magnetron sputtering for stent application. Coatings 2020, 10, 999. [CrossRef]

123. Li, S.; Yi, L.; Zhu, X.; Liu, T. Ultrasonic treatment induced fluoride conversion coating without pores for high corrosion resistance of $\mathrm{Mg}$ alloy. Coatings 2020, 10, 996. [CrossRef]

124. Simchen, F.; Sieber, M.; Mehner, T.; Lampke, T. Characterisation Method of the passivation mechanisms during the pre-discharge stage of plasma electrolytic oxidation indicating the mode of action of fluorides in PEO of magnesium. Coatings 2020, 10, 965. [CrossRef]

125. Toulabifard, A.; Rahmati, M.; Raeissi, K.; Hakimizad, A.; Santamaria, M. The effect of electrolytic solution composition on the structure, corrosion, and wear resistance of PEO coatings on AZ31 magnesium alloy. Coatings 2020, 10, 937. [CrossRef]

126. Yu, B.; Dai, J.; Ruan, Q.; Liu, Z.; Chu, P.K. Corrosion behavior and mechanism of carbon ion-implanted magnesium alloy. Coatings 2020, 10, 734. [CrossRef]

127. Dai, J.; Liu, Z.; Yu, B.; Ruan, Q.; Chu, P.K. Effects of Ti, Ni, and dual Ti/Ni Plasma immersion ion implantation on the corrosion and wear properties of magnesium alloy. Coatings 2020, 10, 313. [CrossRef]

128. Ur Rehman, Z.; Heun Koo, B.; Choi, D. Influence of complex SiF62-ions on the PEO coatings formed on Mg-Al6-Zn1 alloy for enhanced wear and corrosion protection. Coatings 2020, 10, 94. [CrossRef]

129. Fernández, A.G.; Cabeza, L.F. Anodic protection assessment using alumina-forming alloys in chloride molten salt for CSP plants. Coatings 2020, 10, 138. [CrossRef]

130. Zeng, D.; Liu, Z.; Bai, S.; Wang, J. Influence of sealing treatment on the corrosion resistance of PEO coated $\mathrm{Al}-\mathrm{Zn}-\mathrm{Mg}-\mathrm{Cu}$ alloy in various environments. Coatings 2019, 9, 867. [CrossRef]

131. Fu, L.; Yang, Y.; Zhang, L.; Wu, Y.; Liang, J.; Cao, B. Preparation and characterization of fluoride-incorporated plasma electrolytic oxidation coatings on the AZ31 magnesium alloy. Coatings 2019, 9, 826. [CrossRef]

132. Jiang, H.; Cheng, F.; Fang, D. Influence of $\mathrm{TiO}_{2}$ additives on cavitation erosion resistance of Al-Mg alloy micro-arc oxidation coating. Coatings 2019, 9, 521. [CrossRef]

133. Zhang, Y.; Cao, H.; Huang, H.; Wang, Z. Hydrophobic modification of magnesium hydroxide coating deposited cathodically on magnesium alloy and its corrosion protection. Coatings 2019, 9, 477. [CrossRef]

134. Moreno, L.; Mohedano, M.; Mingo, B.; Arrabal, R.; Matykina, E. Degradation behaviour of Mg0.6Ca and Mg0.6Ca2Ag alloys with bioactive plasma electrolytic oxidation coatings. Coatings 2019, 9, 383. [CrossRef] 